\title{
Persistent radical anions in the series of peri-arylenes: broadband light absorption until far in the NIR and purely organic magnetism
}

\author{
Heinz Langhals ${ }^{1} \cdot$ Ulrike Ritter-Faizade $^{1} \cdot$ Philipp Stadler $^{2} \cdot$ Marek Havlicek $^{3} \cdot$ Alexander Hofer $^{1}$. \\ Niyazi Serdar Sariciftci ${ }^{\circledR}$
}

Received: 22 November 2018 / Accepted: 27 February 2019 / Published online: 2 May 2019

(c) The Author(s) 2019

\begin{abstract}
Stable radicals in organic conjugated molecules are of great interest due to their magnetic signals and broad optical absorptions. In this paper, we report on naphthalene, benzoperylene, perylene, terrylene, and quaterrylene carboximides, reduced under controlled conditions, where stable metal-free solid salts of radical anions could be obtained forming darkly colored solutions with line-rich UV/Vis/NIR spectra and exhibiting special magnetic properties. The most bathochromic shift of the absorption maxima extend from 760 until $1700 \mathrm{~nm}$. Persistent paramagnetic properties of the solids were observed and temperature-dependent susceptibilities are measured.
\end{abstract}

\section{Graphical abstract}

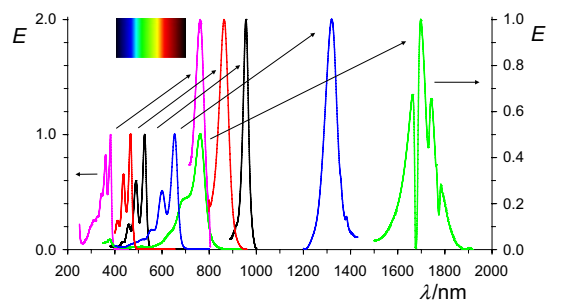

Keywords Perylenes $\cdot$ Photochemistry $\cdot$ Radical anions $\cdot$ Fluorescence $\cdot$ Absorption $\cdot$ Electron spin resonance

\section{Introduction}

Absorption edge of organic compounds is in the ultraviolet (UV) because of large energetic gaps between the highest occupied molecular orbital (HOMO) and highest occupied molecular orbital (LUMO). Shifting light absorption edge

Heinz Langhals

Langhals@1rz.uni-muenchen.de

1 Department of Chemistry, LMU University of Munich, Butenandtstr. 13, 81377 Munich, Germany

2 Linz Institute of Organic Solar Cells (LIOS) and Institute for Physical Chemistry, Johannes Kepler University Linz, Altenbergerstrasse 69, 4040 Linz, Austria

3 Department of Primary Nanometrology and Technical Length, Czech Metrology Institute, Okruzni 31, 6380 Brno, Czech Republic into the visible requires molecular design and band gap engineering [1]. An extended $\pi$-system increases the absorption wavelength to obtain colored materials with lower energetic gaps [2-4]. On the other hand, smaller differences in energy levels are expected within the energetic band structure of the occupied and the unoccupied $\pi$-orbitals of complex aromatic and heteroaromatic systems. Thus, the removing or addition of one electron to an extended $\pi$-system would make these energetic sublevels of $\pi$-band and $\pi^{*}$-band, respectively, accessible for electronic transitions to enable light absorption even until the near infrared (NIR) region. These may be extended far into the IR for sufficiently large electronic systems. However, there is an inherent tendency of such free radicals for dimerization recombination. This may be counteracted by the introduction of charge because of electrostatic repulsion between the molecules. We prefer radical anions avoiding the combination of the electrophilic radical 
cations and aromatics. As a consequence, suitable electron deficient structures are required for the uptake of electrons.

The peri-arylenebiscarboximides [5] $\mathbf{1}$ according to Scheme 1 are known for $n=1$ absorbing in the UV [6, 7] to $n=4$ and, finally, $n=6$ [8] absorbing in the NIR and are attractive starting materials for the preparation of radical anions $\mathbf{2}$ because of their high stability, electron depletion by four carbonyl groups and broad region of tuning of light absorption.

The radical anions $2(n=1)$ of the naphthalenebiscarboximides $\mathbf{1}(n=1)$ were many times reported as intermediates in photochemical processes. The electrochemical reduction of derivatives of $\mathbf{1}(n=1)$ to $\mathbf{2}(n=1)$ was indicated by ESR signals [9]. The same method allowed the preparation of a dark crystalline electrically conducting, however, not further characterized material [10] attributed to 2; this material seemed to be insoluble in polar aprotic solvents because of washing with acetonitrile was described. UV/Vis/NIR spectra of electrochemically prepared 2 were indicated [11]. Chemical reduction of $\mathbf{1}(n=1)$ was described by means of strongly alkaline dithionite [12] solution without further characterization. UV/Vis spectra of radical anions 2 were obtained by flash photolysis and spectroscopically compared [13] with the products from reduction with dithionite and with cobaltocene [14]. A most bathochromic absorption at $777 \mathrm{~nm}$ in dichloromethane can be taken from the graph of the published spectra for the latter. Finally, cyclic triradical trianions were described [15-17].

\section{Results and discussion}

Here, we studied the reduction of the naphthalenebiscarboximides $1(n=1)$ for the synthesis of the radical anions [18] 2 on a preparative scale and applied hydroxyacetone in alkaline media $(\mathrm{NaOH})$ as an efficient, versatile reducing agent where there are well-defined products of the oxidation of the reductone. The preparation of the radical anions $2(n=1)$ was successful in various solvents for both for $R=$ alkyl and $R=$ aryl and was indicated by the bathochromic UV/Vis absorption with a maximum at $761 \mathrm{~nm}$ corresponding to the absorption of the electrochemically prepared radical anions.

However, three topics still remain for the improvement of the synthesis: (i) Over reduction in the redox equilibrium proceeds to the bis-anions $3(n=1)$ under these conditions and is indicated by an absorption at $612 \mathrm{~nm}$ (overlapping with the absorption of 2). The ratio of $\mathbf{2}$ and $\mathbf{3}$ can be controlled by solvent effects where $\mathbf{3}$ dominates in ethanol, $\mathbf{2}$ exceeds in acetone, and about a 1:1 mixture of $\mathbf{2}$ and $\mathbf{3}$ is found in toluene. The equilibrium can be shifted to $\mathbf{2}$ by the addition of diacetyl as a weak oxidant corresponding to the oxidized hydroxyacetone. Thus, solutions can be obtained essentially containing 2 . (ii) The required alkaline medium causes slow hydrolysis of carboximides limiting the stability of solutions; hydrolysis is inhibited if R means a 3-hydroxypropyl group as was found in preceding work [19]; see Scheme 2. Thus, the series of compounds 4 proved to be very resistant concerning alkaline hydrolysis. For example, the refluxing of $\mathbf{4 b}$ or $\mathbf{4 e}$ with 23 equivalents of $85 \% \mathrm{KOH}$ in tert-butylalcohol for $6 \mathrm{~h}$ was not successful for hydrolysis, but only caused slow ring contraction [20] where 4e seems to react even more slowly. The formation of intramolecular hydrogen bonds with a more rigid structure may be, therefore, responsible and are indicated as well by the ${ }^{1} \mathrm{H}$ NMR coupling of the hydroxy hydrogen atoms to form triplets excluding a fast intermolecular proton exchange as sharp bands for the $\mathrm{OH}$ groups between 3480 and $3550 \mathrm{~cm}^{-1}$. A slight shift of the carbonyl absorption of naphthalimides with aliphatic substituents at about 1705 and $1666 \mathrm{~cm}^{-1}$ by $5 \mathrm{~cm}^{-1}$ to lower wavenumbers may be a further indicator. Such intramolecular hydrogen bonds to the carbonyl groups can be verified by means of quantum chemical calculations as shown in Fig. 1.

The application of the non-ionic base DBU (1,8-diazabicyclo[5.4.0] undec-7-ene) [21-23] instead of $\mathrm{NaOH}$ is further favorable for a long-term stability the system. (iii) The solubility of $\mathbf{4}$ is limited constricting general applications and should be enhanced; as a consequence, we introduced geminal long-chain alkyl groups in $\mathbf{4 a}$ to $\mathbf{4 d}$ for increasing solubilization according to Ref. [24].

Considering topics (i)-(iii), we could prepare stable solutions of $5 \mathbf{a}-\mathbf{5 e}$ in ethanol. We precipitated the radical anion by means of an isoionic addition in excess of a salt. Counterions of minor importance for solutions of $\mathbf{5}$, however, fundamentally influence [25] the properties of solid materials. Best results for precipitation were obtained with tetrabutylammonium bromide where the addition of diacetyl proved to be not necessary because the lower solubility of salts of

Scheme 1

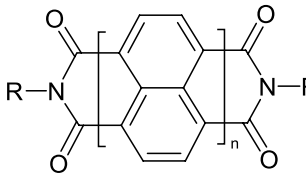

1

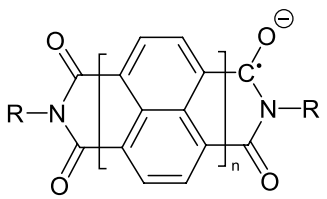

2

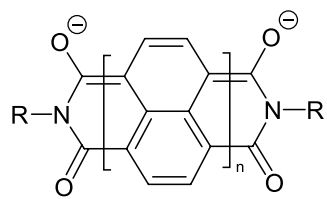

3 


\section{Scheme 2}<smiles>[R]C([R])(CO)CN1C(=O)c2ccc3c4c(ccc(c24)C1=O)C(=O)N(CC([R])([R])CO)C3=O</smiles><smiles>[R]C([R])(CO)CN1C(=O)c2ccc3c4c(ccc(c24)C1=O)C(=O)N(CC([R])([R])CO)C3=O</smiles><smiles>[R]C([R])(CO)Cn1c([O-])c2ccc3c([O-])n(CC([R])([R])CO)c(=O)c4ccc(c1=O)c2c34</smiles>

$4 a-4 e$

$5 a-5 e$

$6 a-6 e$

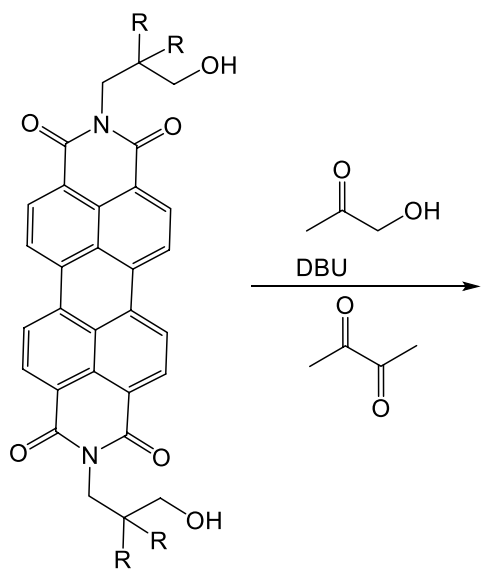<smiles>[R]C([R])(CO)CN1C(=O)c2ccc3c4ccc5c6c(ccc(c7ccc(c2c37)C1=O)c64)C(=O)N(CC([R])(CO)CO)C5=O</smiles>

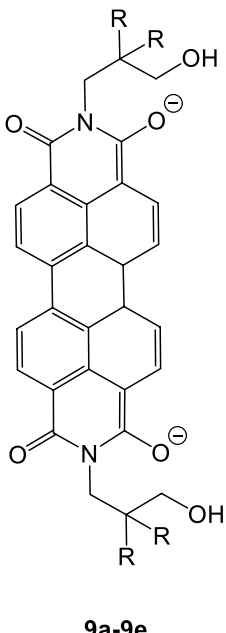

R: a, $\mathrm{C}_{2} \mathrm{H}_{5} ; \mathbf{b}, \mathrm{C}_{3} \mathrm{H}_{7} ; \mathbf{c}, \mathrm{C}_{4} \mathrm{H}_{9} ; \mathbf{d}, \mathrm{C}_{5} \mathrm{H}_{11} ; \mathbf{e}, \mathrm{C}_{8} \mathrm{H}_{17}$

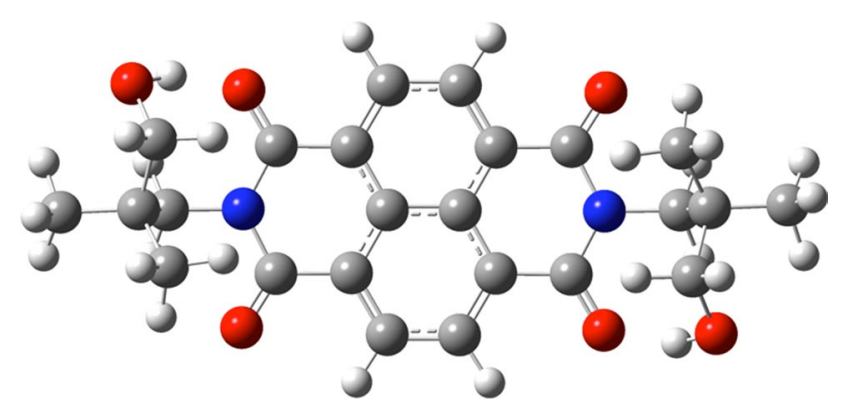

Fig. 1 Quantum chemical (DFT B3LYP) calculated structure of 4 with $\mathrm{R}=\mathrm{CH}_{3}$ (one rotamer is shown); the proximity of the $\mathrm{OH}$ and carbonyl groups can be clearly seen

the radical anions 5 compared with the bis-anion $\mathbf{6}$ allows its selective precipitation along with a shift of the redox equilibria. The solid tetrabutylammonium salts of $\mathbf{5}$ are black solids stable at room temperature for years, if atmospheric oxygen is rigorously excluded; even a brief handling in air is possible because re-oxidation proceeds only slowly. In the IR spectrum, the carbonyl absorption of 5 between 1621 and $1632 \mathrm{~cm}^{-1}$ and for the second band between 1580 and $1587 \mathrm{~cm}^{-1}$ are appreciably shifted to lower wavenumbers compared with $\mathbf{4}$ and can be taken as an indicator for a weakening of the $\mathrm{C}=\mathrm{O}-$ double bond by the delocalization of the unpaired electron in $\mathbf{5}$. Even the $\mathrm{C}=\mathrm{C}-$ vibration was shifted to lower wavenumbers and found at 1556 and $1520 \mathrm{~cm}^{-1}$. In the ${ }^{1} \mathrm{H}$ NMR spectrum the signals of the tetrabutylammonium cation could be observed and signals from the periphery of the anion whereas the resonances of the aromatic protons could not be detected; this was attributed to appreciable line broadening and can be taken as a proof for the unpaired electron in 5. A further proof was given by high-resolution anion mass spectroscopy. The solid radical salts can be re-dissolved to obtain reddish brown solutions containing exclusively the radical anion. Such solutions can be stored without decomposition for many months if atmospheric oxygen is rigorously excluded (handling becomes 
simplified by a stabilization with hydroxyacetone and DBU concerning traces of oxygen). Obviously, disproportionation is kinetically inhibited.

The reduction of perylenes $\mathbf{1}(n=2)$ was studied as the next higher homologues of the peri-arylenes. Radical anions of perylenebiscarboximides $2(n=2)$ were firstly described [26] in 1978 and electrochemically generated [27-29] by the reduction of $1(n=2)$. A further electron depletion by means of trifluoromethyl groups allowed the isolation of salts of radical anions [30-34]. In this work, the generally pigment-like perylenecarboximides $\mathbf{1}(n=2)$ were solubilized by means of long-chain sec-alkyl groups such as the 1-hexylheptyl group at their nitrogen atoms and reduced with hydroxyacetone in alkaline solution to form $\mathbf{2}(n=2)$ : Mostly over-reduction to the bis-anion $3(n=2)$ and slow hydrolysis of the carboximide groups proceeded. Here, we applied the same strategy for the preparation of the more stabilized $\mathbf{8}$ as was described for $\mathbf{5}$. Thus, perylene tetracarboxydiimides 7 were protected against hydrolysis [19] with 3-hydroxyalkyl groups analogously to $\mathbf{4}$, and reduced with hydroxyacetone and $\mathrm{NaOH}$ to form surprisingly stable products which are now the focus of the following discussion. Over reduction proceeded for $\mathbf{7 a}-\mathbf{7 e}$ under these conditions to mainly form the bis-anions $9 \mathbf{9}-\mathbf{9 e}$, whereas only some radical anions 8a-8e are found in the equilibrium; this may be a consequence of the electron-withdrawing effect of the hydroxy groups in the side chains of $\mathbf{7}$ stabilizing the higher charged bis-anion. The equilibrium can be shifted to the radical anions $\mathbf{8}$ by the addition of the weak oxidant diacetyl. The radical anions $\mathbf{8}$ can be precipitated from the reduced solution by the addition of tetra- $n$-butyl ammonium bromide. The preferred precipitation of the $\mathbf{8}$ compared with the bis-anions 9 may be a consequence of the more efficient lowering of the solubility by the isoionic addition of the ammonium salt for 8 than for the bis-anions (compare the reduction of 4). The precipitated radical anions 8 form bluish dark solids and seemingly can be stored indefinitely under protective atmosphere such as argon. 8a and $\mathbf{8 b}$, respectively, can be even briefly handled in air; however, slow oxidation proceeds to convert the substance back to the staring materials $\mathbf{7 a}$ and $\mathbf{7 b}$, respectively. Essentially, solutions of the radical anions $\mathbf{8}$ are obtained on re-dissolution of the solids being comparably stable; disproportionation of $\mathbf{8}$ to 7 and 9 seems to be kinetically inhibited. The re-oxidation of the dissolved $\mathbf{8}$ with air to the starting material $\mathbf{7}$ proceeds much more quickly than for the solids. A trapping of the dissolved anions $\mathbf{8}$ by electrophiles such as protons, acetic anhydride or trimethylsilyl chloride was not successful because the starting materials $\mathbf{7}$ were spontaneously formed after the contact with any such reagents. Even an addition of concentrated solutions of $\mathrm{NH}_{4}^{+}, \mathrm{Mg}^{2+}, \mathrm{Ca}^{2+}, \mathrm{Ba}^{2+}, \mathrm{Li}^{+}$, $\mathrm{Na}^{+}, \mathrm{K}^{+}$, and $\mathrm{Zn}^{2+}$ salts caused the formation of the starting materials 7. The NMR spectra of dissolved $\mathbf{8}$ are typical for paramagnetic materials because only signals of the $n$-butyl groups of the counter ions were found and signals from the aliphatic periphery, whereas the signals of the aromatic core of radical anion were lost by strong line-broadening because of unfavorable relaxation processes. Spin and charge of radical anions $\mathbf{8}$ seem to be fully delocalised because both the carbonyl and $\mathrm{C}=\mathrm{C}$ valence frequencies are lowered in the IR spectrum from 1688 and 1638 for the starting material [32] to 1601 and $1542 \mathrm{~cm}^{-1}$ for $\mathbf{8 b}$ and even for the frequencies of the $\mathrm{C}=\mathrm{C}$ vibrations from 1595 and 1579 to 1560 and $1492 \mathrm{~cm}^{-1}$ for $\mathbf{8 b}$ indicating a weakening of these bonds. The radical-type character of the solids $\mathbf{8}$ is univocally indicated by their ESR spectra both of the solids and the re-dissolved material where signals with no hyper-fine structures were found; see below. The negative charge of $\mathbf{8}$ is indicated by anion mass spectrometry.

The more bathochromically shifted absorbing terrylenecarboximides [35] $1(n=3)$ were targeted as the next higher homologue; see Scheme 3. The formation of radical anions $2(n=3)$ was reported for the electrochemical reduction [36] of $\mathbf{1}(n=3)$ and indicated by their UV/Vis/NIR absorption. Thus, we studied the isolation of $\mathbf{2}(n=3)$ and found a minor pronounced tendency for hydrolysis compared with the lower homologues, presumably because of the higher electron density of $\mathbf{1}(n=3)$. As a consequence, we substituted the nitrogen atoms of $\mathbf{1}(n=3)$ with the highly solubilising 1-hexylheptyl group (swallow tail substituent) to prepare $[37,38] \mathbf{1 0}$. However, no $\mathbf{1 1}$ was obtained by a reduction with hydroxyacetone because a complete over reduction proceeded to the bis-anion 12 absorbing at 694 nm; see Fig. 4. The reducing aptitudes of hydroxyacetone and DBU could be balanced with the addition of diacetyl to the formation of the radical anion $\mathbf{1 1}$ indicated by a color change from deep blue to greenish blue. Finally, a precipitation with tetra$n$-butylammonium bromide was successful to obtain the salt of $\mathbf{1 1}$ as a dark blue solid.

Quaterrylene tetracarboxybisimides [39, 40] $1(n=4)$ being known to be very bathochromically absorbing were rendered soluble [41, 42] by the $N$-(1-hexylheptyl) substituents to obtain 13 and reduced according to 4 . Complete over reduction proceeded to the slightly more bathochromically absorbing bis-anion 15 at $803 \mathrm{~nm}$; see Fig. 5. The reducing aptitude of hydroxyacetone was controlled by the addition of diacetyl finally to obtain $\mathbf{1 4}$. This radical anion could be precipitated by the addition of tetra- $n$-butylammonium bromide to obtain the radical salt of $\mathbf{1 4}$ as a dark green solid. The solid material can be stored under inert atmosphere without decomposition.

We extended the application of the method of reduction to even larger laterally conjugated systems. Thus, we studied the reduction of benzoperylenehexacarboxytrisimides [43] analogously to $\mathbf{1}$ to form $\mathbf{2}$ and tried to protect the starting material against alkaline hydrolysis analogously to 7 with 3-hydroxyalkyl groups. However, the 
Scheme 3

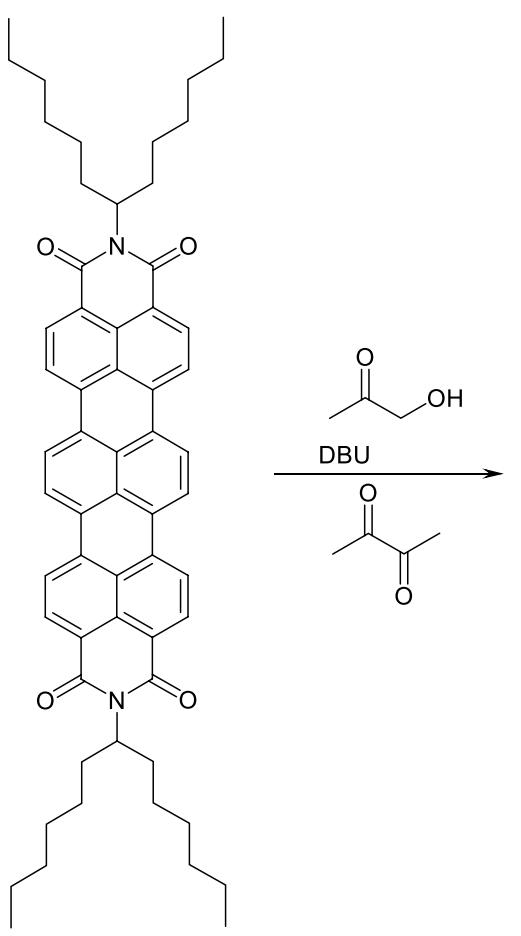

10

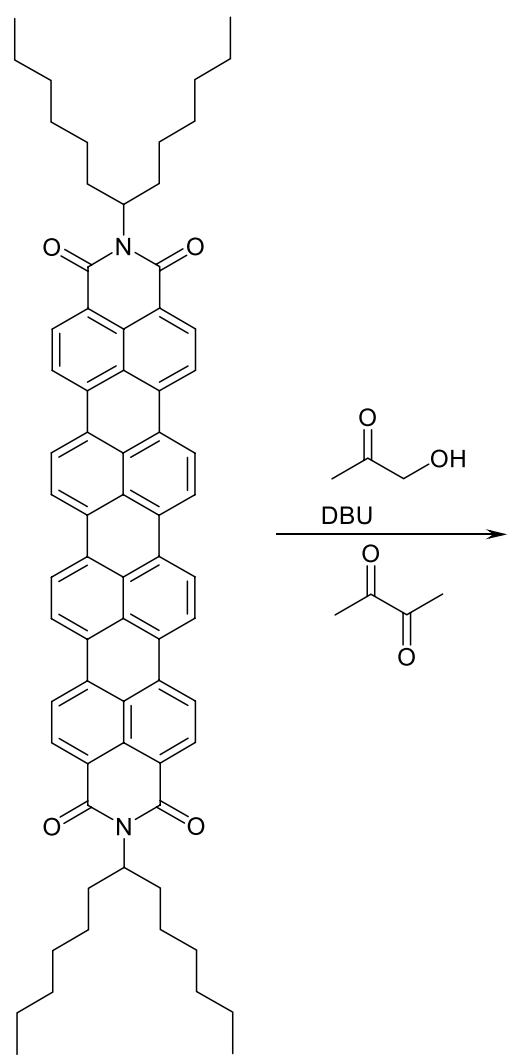

13

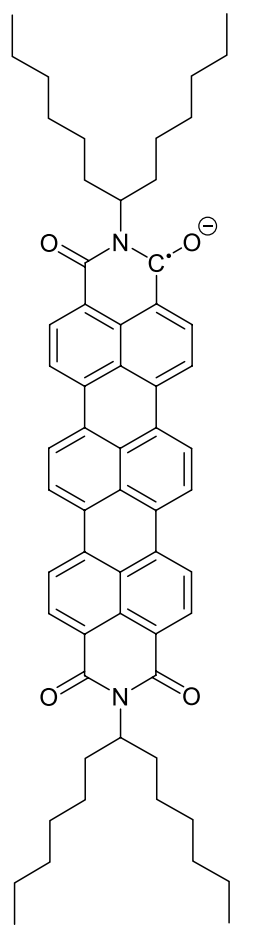

11
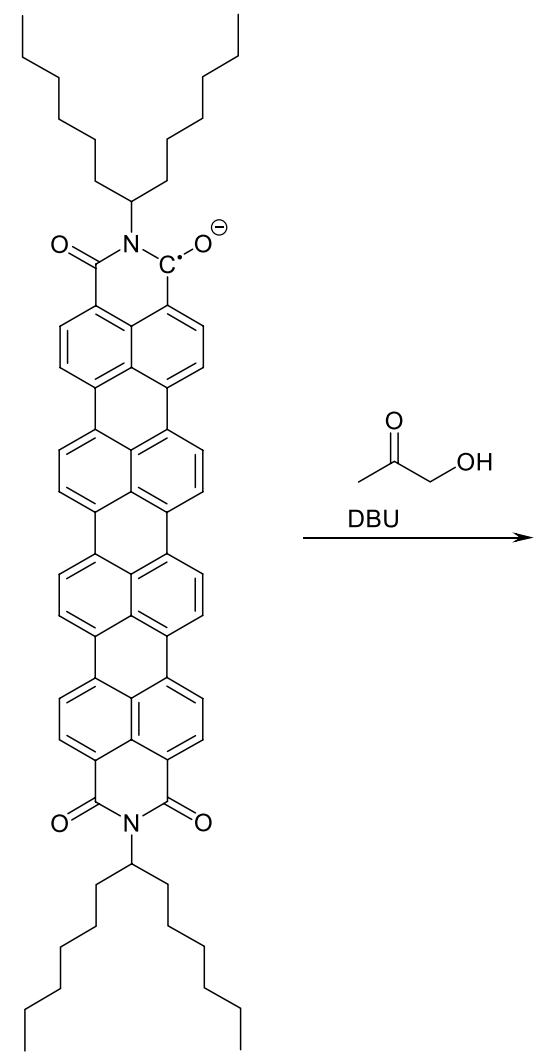

14
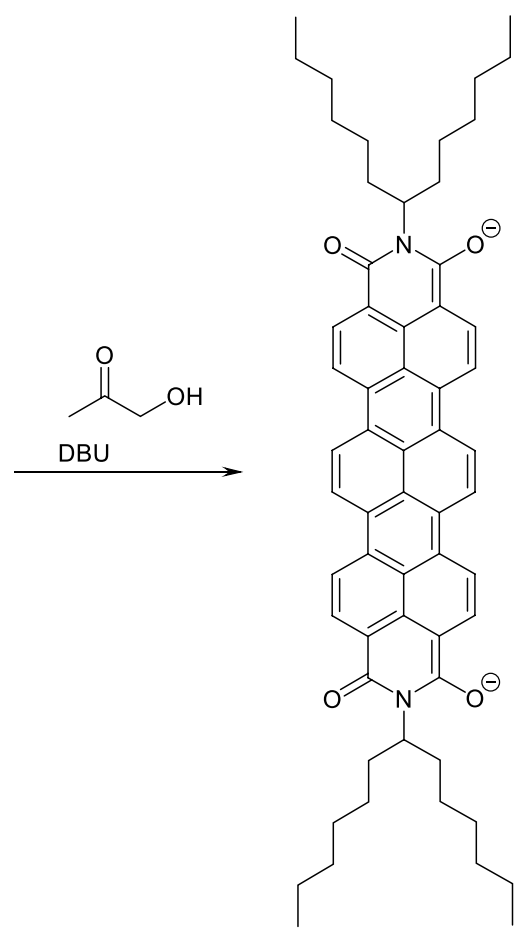

12

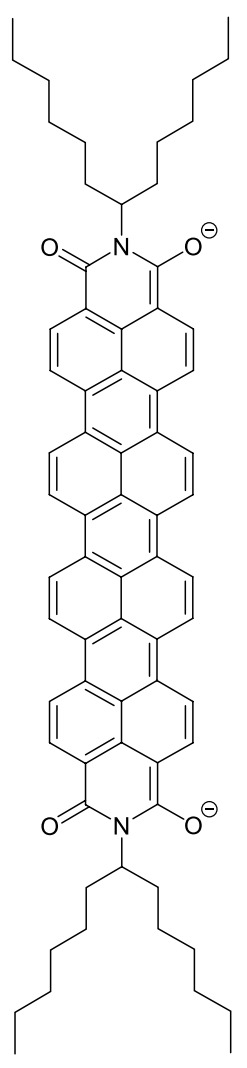

15 


\section{Scheme 4}

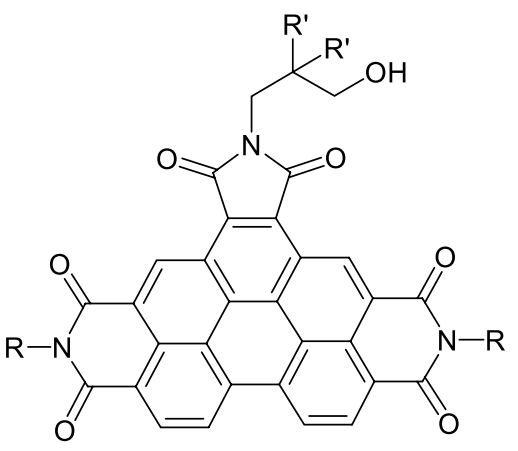

16<smiles>CC(=O)CO</smiles>

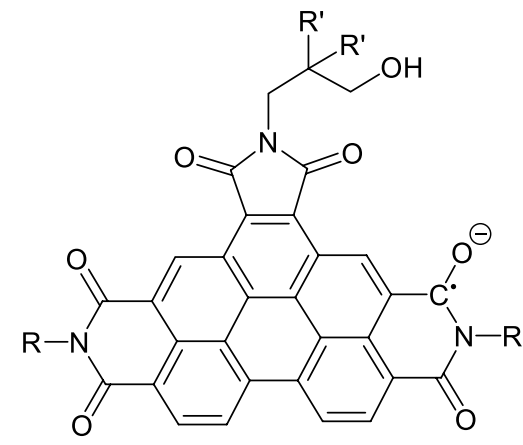

17

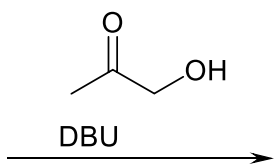<smiles></smiles>

$\mathrm{R}=\mathrm{CH}\left(\mathrm{C}_{6} \mathrm{H}_{13}\right)_{2}$

$\mathrm{R}^{\prime}=\mathrm{C}_{8} \mathrm{H}_{17}$ synthesis of the staring material by the Clar variant of the Diels-Alder reaction of 7e with maleic anhydride was not successful, presumably because of the still low solubility. As a consequence, we allowed to react the better soluble perylene derivative $\mathbf{1}$ ( $n=3, \mathrm{R}=1$-heyxlheptyl) to form the core-extended anhydride and tried to condense it with 2-aminomethyl-2-octyldecan-1-ol to form $\mathbf{1 6}$ to protect the more labile five-membered ring; Scheme 4. However, the condensation of the anhydride group with hydroxy amines

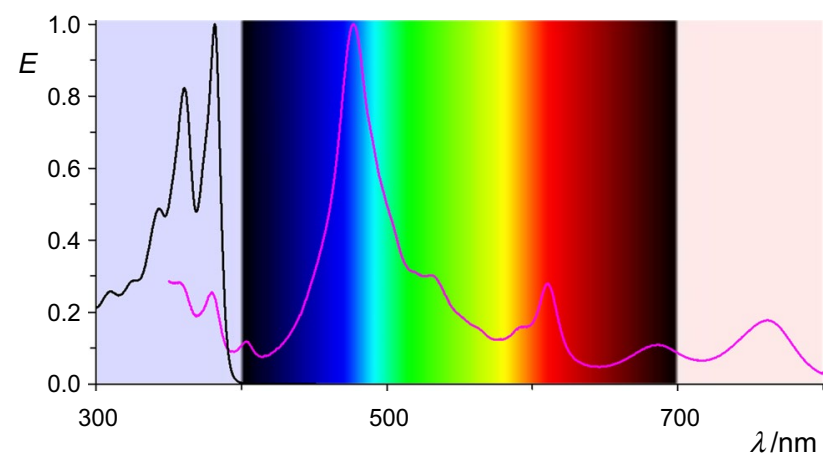

Fig. 2 UV/Vis/NIR spectra of $\mathbf{5 c}$ (in acetone, stabilized with hydroxyacetone, magenta curve) compared with $\mathbf{4 c}$ (in chloroform, black curve in the UV) by means of imidazole under standard conditions [44] was not successful, but could be achieved with DCC and TFA in chloroform [45] to form the benzoperylene hexacarboxytrisimide 16 with two efficiently solubilising [46] swallow-tail substituents $(\mathrm{R})$ and one hydrolysis protecting group $\left(\mathrm{R}^{\prime}\right)$ attached to the more labile five-membered ring causing an acceptable stabilization concerning hydrolysis.

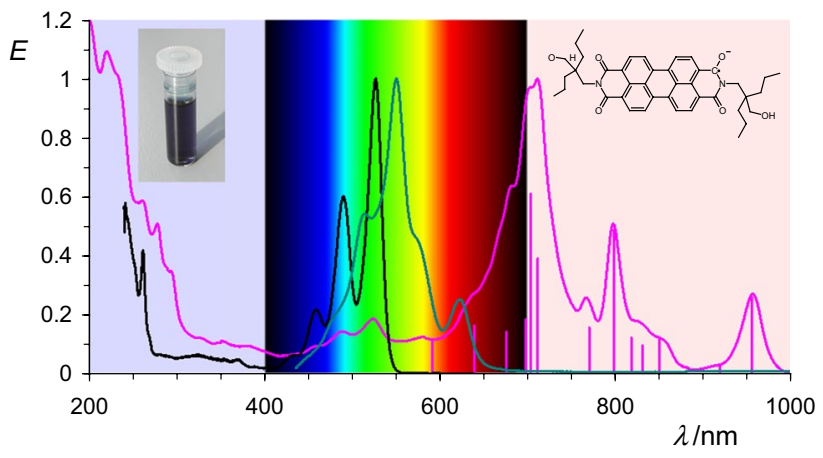

Fig. 3 UV/Vis/NIR absorptions spectra of $\mathbf{8 b}$ in acetonitrile (right line in magenta), the bis-anion $\mathbf{9 b}$ (middle line in green) in acetone, and the starting material $\mathbf{7 b}$ (left line in black) in chloroform. Bars: line positions obtained by a Gaussian analysis of the spectrum of $\mathbf{8 b}$ 
The benzoperylenehexacarboxytrisimide was reduced by the application of hydroxyacetone and precipitated with tetrabutylammonium bromide to form the salt of $\mathbf{1 7}$ as a yellowish dark green solid being much more sensitive versus oxygen than $\mathbf{8}$. The precipitated $\mathbf{1 7}$ can be stored if oxygen is carefully excluded. The material is appreciably less stable in solution than $\mathbf{8}$ and rapidly decomposes during the UV/Vis spectroscopic measurements.

The band-rich UV/Vis absorption spectrum of $\mathbf{5 c}$ with the most bathochromic maximum at $761 \mathrm{~nm}$ is reaching NIR and is shown in Fig. 2. Fluorescence could not be detected as was expected.

The solids of $\mathbf{8}$ form characteristically dark blue solutions in solvents such as acetonitrile or acetone where the color is not caused by the most bathochromic electron transition, but by a transition to higher electronic levels, and thus presents an example of colors of second order [47-50]. The most bathochromic absorption maximum is far in the NIR at $957 \mathrm{~nm}$ and there are many bands in the spectrum; see Fig. 3. The UV/Vis absorption of $\mathbf{8}$ corresponds to the

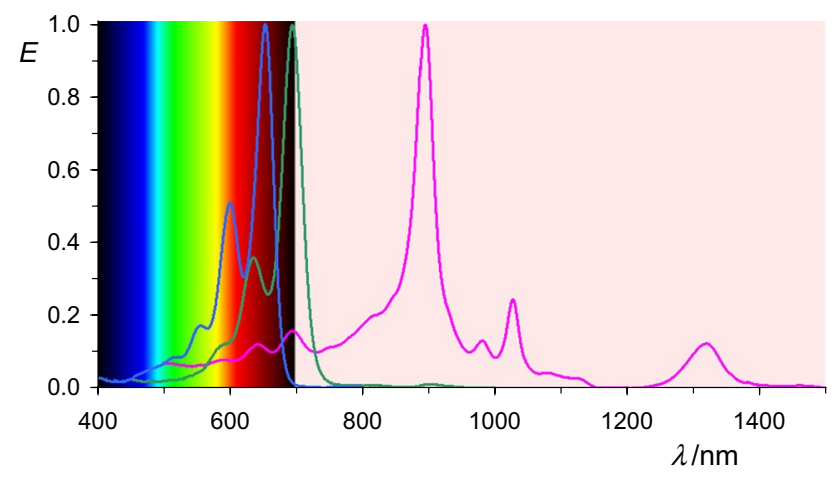

Fig. 4 UV/Vis/NIR absorptions spectra of $\mathbf{1 1}$ stabilized in acetone (right line in magenta), the bis-anion $\mathbf{1 2}$ (middle in green) and the starting material $\mathbf{1 0}$ (left line in blue)

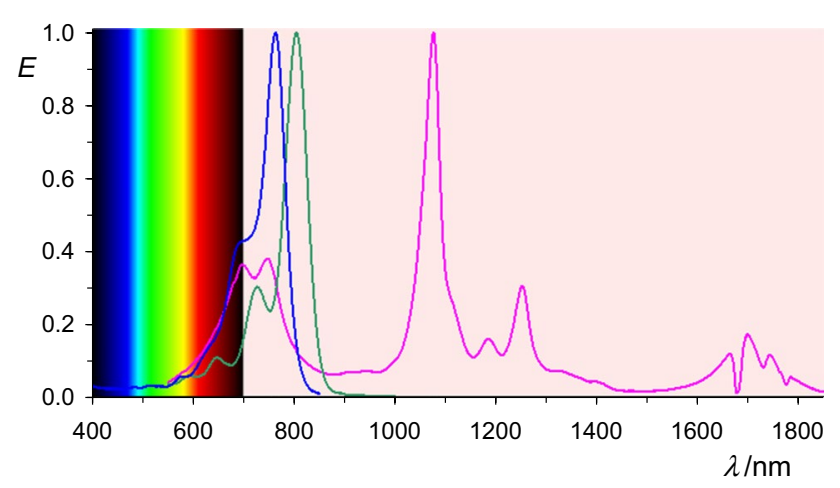

Fig. 5 UV/Vis/NIR absorptions spectra of $\mathbf{1 4}$ stabilized in acetone (right line in magenta), the bis-anion $\mathbf{1 5}$ (middle line in green) and the starting material $\mathbf{1 3}$ (left line in blue); interference in the bathochromic region by the absorption of the medium previously reported absorption of the electrochemically [18, $29,36]$ generated transient coloration by derivatives of $\mathbf{8}$. Solid-state UV/Vis/NIR spectroscopy is used to confirm independently the radical character of $\mathbf{8}$ because a strong bathochromic absorption at $957 \mathrm{~nm}$ is observed being identical with respect to the dissolved material.

The terrylene-based radical anion $\mathbf{1 1}$ absorbs as bathochromic as $1320 \mathrm{~nm}$; see Fig. 4. The absorption of the latter is mainly in the NIR, so that color is caused by residual bands in the visible.

Finally, the quaterrylene-derived precipitated radical anion $\mathbf{1 4}$ was re-dissolved where the solution in acetone absorbs in the UV/Vis/NIR as bathochromic as $1699 \mathrm{~nm}$ being not far away from the region of vibration spectra; see Fig. 5.

The lateral extension of the perylenes to benzoperylenes causes a hypsochromic shift such as that shown in Fig. 6 for 16. The UV/Vis spectrum of the radical anion $\mathbf{1 7}$ obtained by the reduction of $\mathbf{1 6}$ still extends to the NIR at $867 \mathrm{~nm}$.

\section{Magnetic properties of the radical anions}

The radical-type character of the solids $\mathbf{8}$ as well as in solutions is univocally indicated by their ESR spectra both of the solids and the re-dissolved material where signals with no hyper-fine structures were found; see Fig. 7.

\section{Magnetic measurements}

Organic magnetic materials are of general interest because special effects can be expected such as the ferromagnetism, giant magnetoresistance, magnetic Seebeck effect, etc.; the low heat conductivity of organic materials is important for the latter [51-54]. The unpaired spin of 5a and 8a, respectively, persists in the solid state and allows the study of

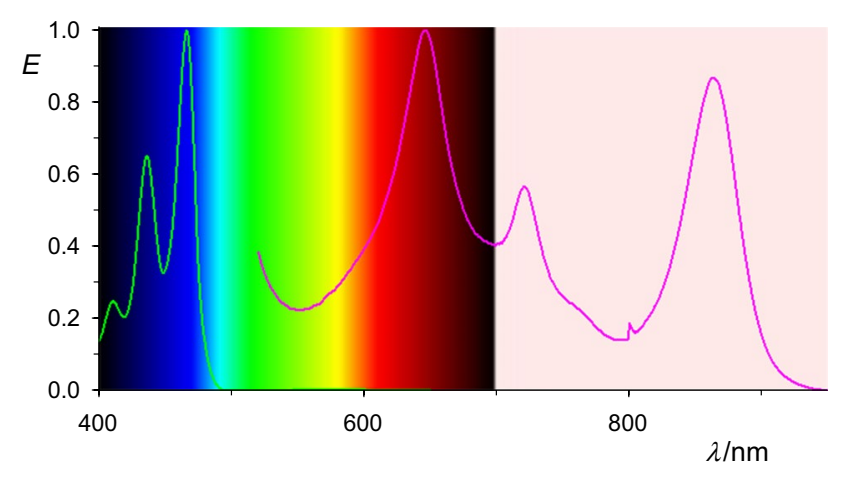

Fig. 6 UV/Vis/NIR absorptions spectra of $\mathbf{1 7}$ stabilized in acetone (right line in magenta) with bathochromic-shifted feature with peak maxima at $718 \mathrm{~nm}$ and $867 \mathrm{~nm}$ and the starting material 16 (left line in green). Absorption maxima of the bis-anion $\mathbf{1 8}$ were found at $535 \mathrm{~nm}$ and $580 \mathrm{~nm}$ 

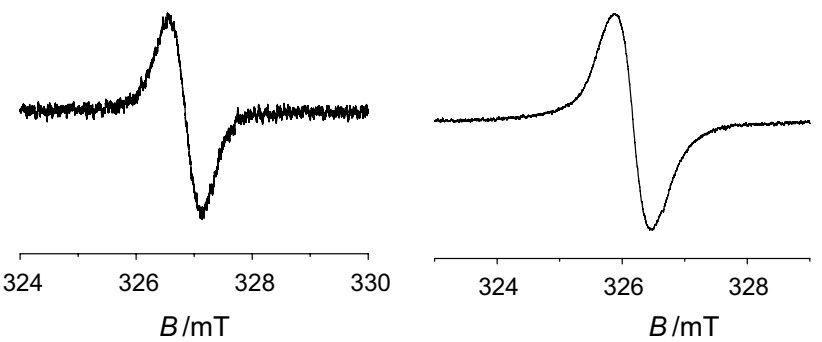

Fig. 7 ESR spectra of 8a. Left in acetone $(g=2.0038)$, right in the solid state $(g=2.0041)$

magnetic ordering. The ESR signal of the solid naphthalene derivative 5a shows an irregular line shape which consists of more (up to three) overlapping lines with slightly shifted $g$-factors; Fig. 8, left. The $g$-factor of the main peak was found to be 2.0035 . The signal undergoes line broadening upon cooling. We have observed change in amplitudes of individual signals after exposure to air which was partially reversible after re-evacuation. No detailed evaluation of signal amplitudes for samples exposed intentionally to air was performed due to the complex nature of their behavior.

The ESR signal of the solid perylene derivative $\mathbf{8 a}$ shows a more regular line shape; Fig. 8, right. Unwanted passage effects led us to work at very low microwave power with attenuation set to $40 \mathrm{~dB}(20 \mu \mathrm{W})$, modulation amplitude $0.1 \mathrm{G}$, and modulation frequency $10 \mathrm{kHz}$ to prevent any unwanted signal distortion. Perylene $g$-factor was found to be 2.0031. Small line broadening upon cooling was observed also in $7 \mathbf{a}$ but not as significant as in the naphthalene derivative $4 \mathbf{a}$.

In the next step, we took a closer look at the magnetic behavior of the material. Figure 9 shows the normalized temperature dependence of doubly integrated ESR signals which corresponds to the magnetic susceptibility of the sample under study. Inset shows the temperature dependence of inverse susceptibility.

$\chi \sim \frac{C}{\left(T-T_{C}\right)^{\gamma}}$

Using the Curie-Weiss law (Eq. 1) where $C$ is a Curie constant, $T$ is the absolute temperature in Kelvin, $T_{C}$ is the Curie temperature, and $\gamma$ is critical exponent, it is possible to determine the character of magnetism (Fig. 10 fits). We observe that $T_{C}$ and $\gamma$ are close to 0 (i.e., $2-3 \mathrm{~K}$ ) and close to unity, respectively. This indicates a paramagnetic behavior. Figure 10 shows in a more illustrative way the (paramagnetic) regime for both materials as the temperature dependence of the product $\chi T$.

\section{Compressed solids}

The solid materials $5 \mathbf{a}$ and $\mathbf{8 a}$ were compacted in vacuo by the application of pressure of 2700 bar ( 3 tons at $12 \mathrm{~mm}$ piston). The diagrams of Fig. 11 indicate paramagnetic properties for both compacted solids.

We calculated the number of free spins using the absolute intensities of the ESR signals. We found $1.5 \times 10^{16}$ free spins at room temperature, where $1.5 \times 10^{16}$ spins were found for $0.8 \mathrm{mg}$ of compressed $\mathbf{5 a}\left(1.9 \times 10^{19} \mathrm{spins} / \mathrm{g} ; 0.025 \mathrm{~mol}\right.$ spins $/ \mathrm{mol})$ and $1.1 \times 10^{17}$ for $2.8 \mathrm{mg}$ of compressed $\mathbf{8 a}$ $\left(3.8 \times 10^{19} \mathrm{spins} / \mathrm{g} ; 0.060 \mathrm{~mol}\right.$ spins $\left./ \mathrm{mol}\right)$. This corresponds to one free spin for 40 molecules of $\mathbf{5 a}$ and one free spin for 17 molecules of $8 \mathbf{a}$.
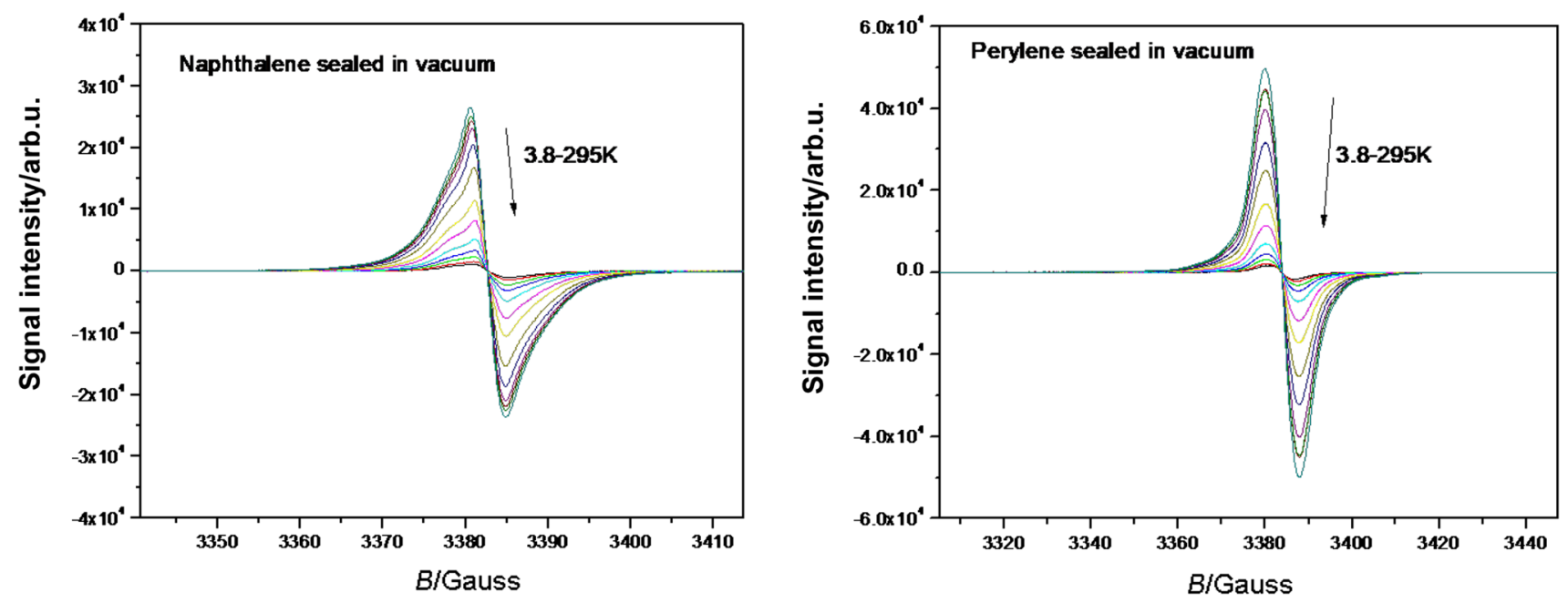

Fig. 8 The temperature dependences of solid-state ESR signals recorded for the naphthalene (2, left) and the perylene $(\mathbf{4}$, right) derivatives in the temperature range $3.8-300 \mathrm{~K}$ 

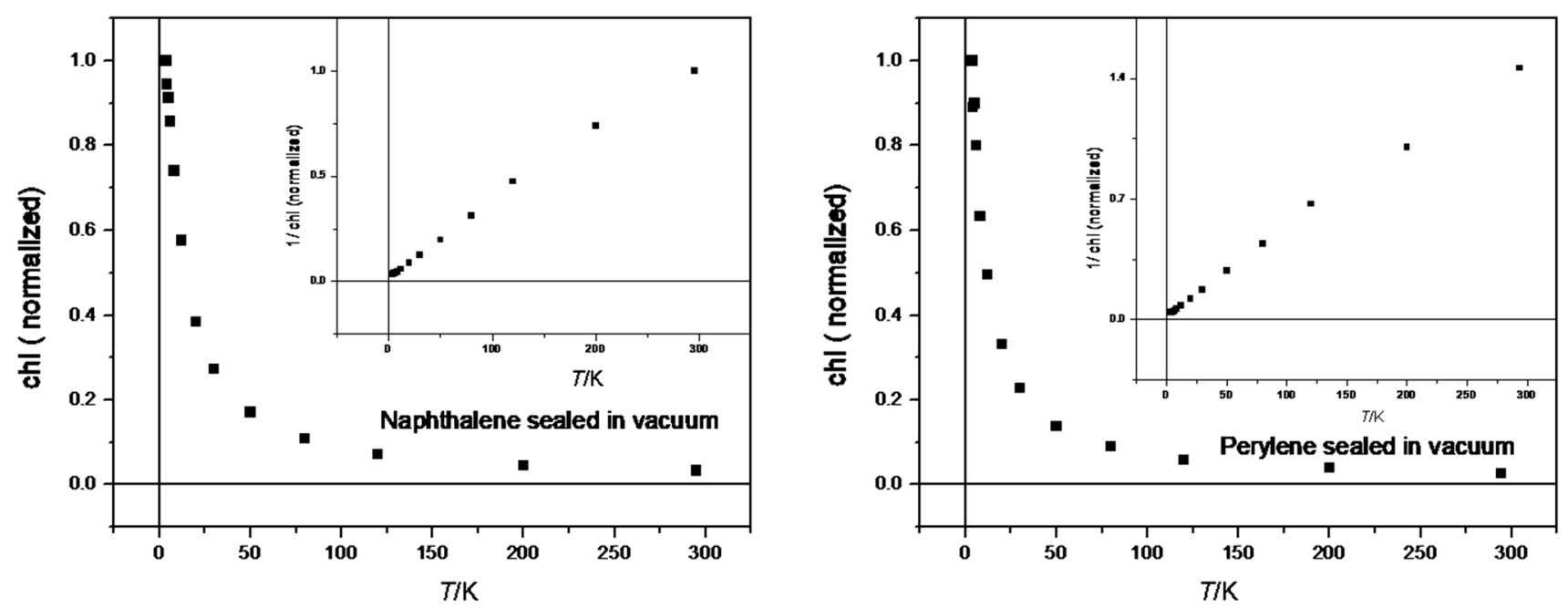

Fig. 9 Temperature dependence of normalized magnetic susceptibility for solid naphthalene (5a, left) and perylene (8a, right) radicals anions evaluated from ESR measurements in the temperature range $3.8-300 \mathrm{~K}$ (squares). Plot of $1 / \chi$ vs. temperature is shown in the inserts
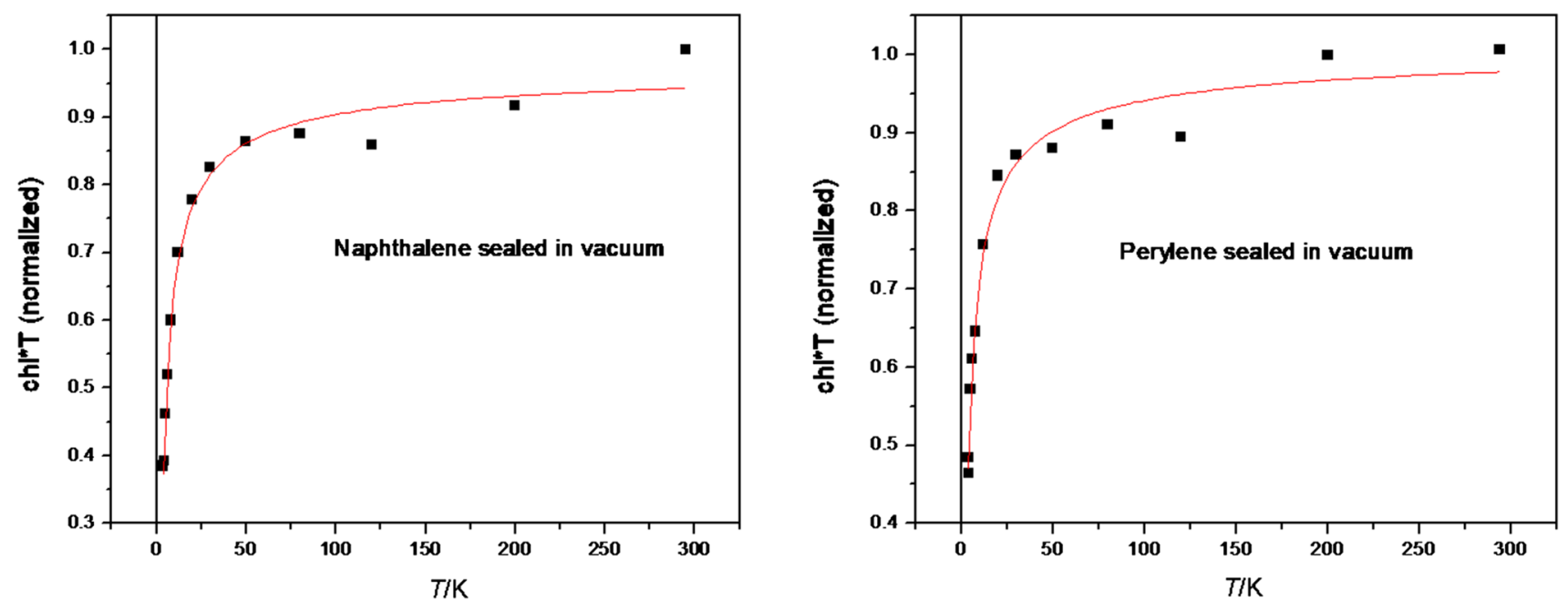

Fig. 10 Temperature dependence of normalized magnetic susceptibility $* T$ for naphthalene and perylene radicals evaluated from ESR measurements in the temperature range $3.8-300 \mathrm{~K}$ (squares). Continuous line is the best fit to Eq. (1)

\section{Conclusion}

We conclude that (bathochromically) shifted UV/Vis/NIR absorptions can be obtained by the reduction of suitable chromophores to their radical anions where an overview of peri-arylenes is shown in Fig. 12. The isolated radical anions promise many novel applications for dyestuff applications. The problems in conventional vat dying with the heavy-load of alkali being damaging delicate surfaces such as silk or human hair can be overcome by decoupling the processes of reduction and re-oxidation. The replacement of the environmentally problematic dithionite by hydroxyacetone or even electrochemical [55] processes for vat dyeing and the precipitation of the radical salts may turn such processes to green chemistry. The vat dying with the colorless 1 may be of special advantage because of sun-protection concerning UVA [56, 57]. This may be useful for the protecting of fibers and other materials, and also for sun-protecting clothes. Even the radical anions may be useful for many applications because of their bathochromic shifts of light absorption, their sensitivity against atmospheric oxygen can be solved by encapsulation such as in laminated compound glass. 

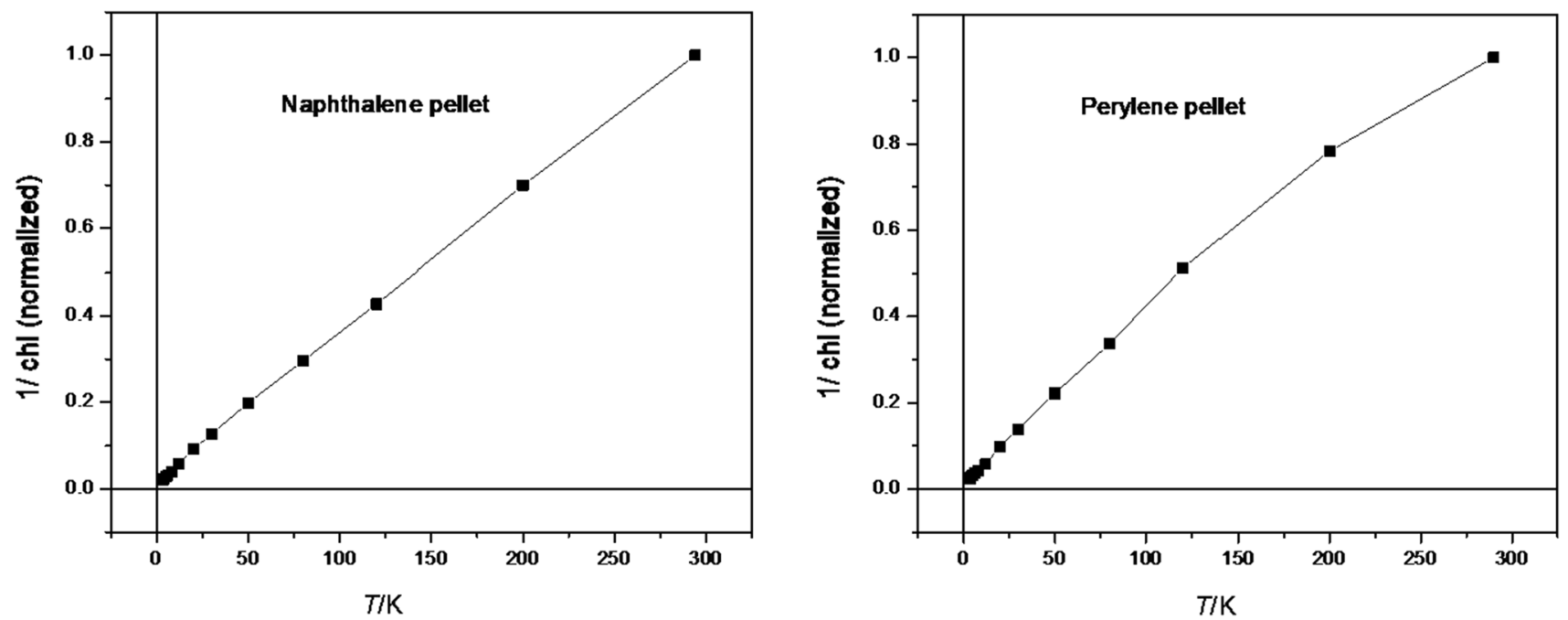

Fig. 11 Temperature dependence of normalized magnetic susceptibility for compressed solid naphthalene (4a, left) and perylene (7a, right) radicals anions in the temperature range $3.8-300 \mathrm{~K}$ : plot of $1 / \chi$ vs. temperature

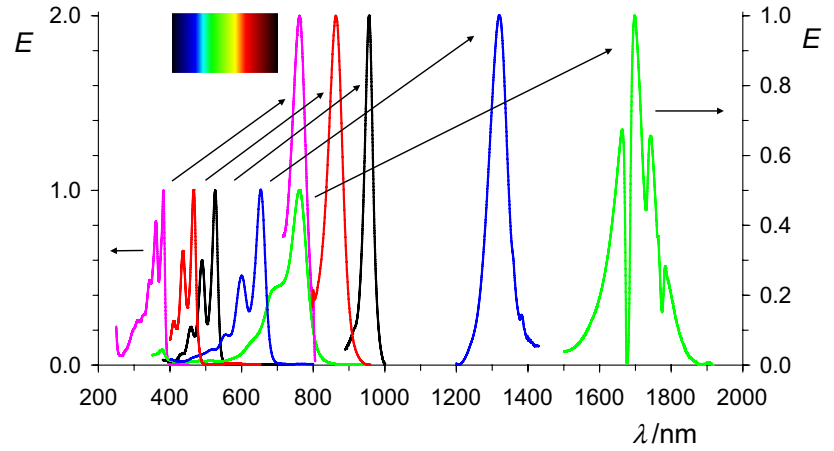

Fig. 12 Overview: normalized UV/Vis/NIR absorptions spectra of oligo peri-arylenetetracarboxydiimides 1 in chloroform (lower lines, left with the left scale) compared with the most bathochromic-shifted absorption of their radical anions 2 in acetone (higher lines, right, right scale); from left to right: magenta: $\mathbf{4 b}$, red: $\mathbf{1 6}$, black: $\mathbf{7 b}$, blue: 10, green 13; and magenta: 5b, red: 17, black: 8b, blue: 11, green 14 . Upper left: colors of the rainbow spectrum

\section{Experimental}

All reagents were used as received from commercial suppliers. The solvents used in the reactions were dried with standard drying agents and freshly distilled prior to use. Reaction progress was monitored by thin-layer chromatography (TLC) on E. Merck Kieselgel 60 F254. Column chromatography was performed using silica gel (60 $\AA$ A , 40-63 $\mu \mathrm{m}$, ROCC). IR spectra were recorded as ATR with a Perkin Elmer 1420 Ratio Recording Infrared Spektrometer, FT $1000\left(4000-450 \mathrm{~cm}^{-1}\right)$. UV/Vis/NIR spectra: Varian Cary 5000; fluorescence spectra: Perkin Elmer FS 3000 (totally corrected). All ${ }^{1} \mathrm{H}$ and ${ }^{13} \mathrm{C}$ NMR spectra were recorded with a Varian Vnmrs $600(600 \mathrm{MHz})$ in $\mathrm{CDCl}_{3}$ at $25^{\circ} \mathrm{C}$. Chemical shifts $(\delta)$ are reported in ppm and coupling constants $(J)$ in Hz. Mass spectra were performed using a Finnigan MAT 95. Elemental analyses $(\mathrm{C}, \mathrm{H}, \mathrm{N})$ were conducted using the Elemental Analyser Elementar Vario EL from Elementar Analysensysteme GmbH. ESR spectra were measured with an JES-RE2X ESR spectrometer from Jeol; $\mathrm{X}$-band spectra in thin capillaries were recorded.

2-Cyano-2-octyldecanoic acid methyl ester $\left(\mathrm{C}_{20} \mathrm{H}_{37} \mathrm{NO}_{2}\right) 18 \mathrm{~cm}^{3}$ cyanoacetic acid methyl ester $(200 \mathrm{mmol})$ and $70 \mathrm{~cm}^{3}$ 1-bromooctane $(400 \mathrm{mmol})$ were slightly warmed with the exclusion of air and treated dropwise with $91 \mathrm{~cm}^{3}$ of a solution of $25 \%$ sodium methanolate in methanol $(400 \mathrm{mmol})$, refluxed for $8 \mathrm{~h}$, stirred at room temperature for $16 \mathrm{~h}$, treated with $100 \mathrm{~cm}^{3}$ distilled water for the dissolution of the precipitate of sodium bromide, concentrated by the evaporation of methanol, collected by the extraction with $1 \times 100 \mathrm{~cm}^{3}$ and $2 \times 50 \mathrm{~cm}^{3}$ diethyl ether, dried with magnesium sulfate, evaporated, and distilled in medium vacuo. Yield $43.5 \mathrm{~g}$ (135 mmol, 67\%) colorless liquid; b.p.: $155-162{ }^{\circ} \mathrm{C}\left(9 \times 10^{-3}-1.6 \times 10^{-2}\right.$ mbar); IR (ATR): $\bar{v}=2955$ (s), 2925 (s), 2856 (s), 2244 (w), $1745(\mathrm{~s}), 1458(\mathrm{~m}), 1379(\mathrm{w}), 1232(\mathrm{~m}), 1177(\mathrm{w})$, 1137 (w), 1079 (w), 775 (w), $723 \mathrm{~cm}^{-1}$ (w); ${ }^{1} \mathrm{H}$ NMR $\left(600 \mathrm{MHz}, \mathrm{CDCl}_{3}\right): \delta=0.88\left(\mathrm{t}, 6 \mathrm{H},{ }^{3} J=7.0 \mathrm{~Hz},-\mathrm{CH}_{3}\right) 1.30$ $\left(\mathrm{m}, 22 \mathrm{H},-\mathrm{CH}_{2}\right), 1.55\left(\mathrm{~m}, 2 \mathrm{H},-\mathrm{CH}_{2}\right), 1.76\left(\mathrm{~m}, 2 \mathrm{H},-\mathrm{CH}_{2}\right)$, $1.88\left(\mathrm{dt}, 2 \mathrm{H},{ }^{3} \mathrm{~J}=4.0 \mathrm{~Hz},{ }^{2} \mathrm{~J}=13.3 \mathrm{~Hz}, \mathrm{CH}_{2}\right), 3.81(\mathrm{~s}, 3 \mathrm{H}$, $\left.-\mathrm{OCH}_{3}\right) \mathrm{ppm} ;{ }^{13} \mathrm{C} \mathrm{NMR}\left(150 \mathrm{MHz}, \mathrm{CDCl}_{3}\right): \delta=14.1,22.6$, 25.4, 29.1, 29.2, 31.8, 50.0, 53.2, 119.5, 169.9 ppm; MS $\left(\mathrm{DEI}^{+} / 70 \mathrm{eV}\right): \mathrm{m} / z(\%)=324(1), 323(3)\left[\mathrm{M}^{+}\right], 322(3), 264$ (15) $\left[\mathrm{M}^{+}-\mathrm{CO}_{2} \mathrm{CH}_{3}\right], 212$ (7), $211(42)\left[\mathrm{M}^{+}-\mathrm{C}_{8} \mathrm{H}_{17}\right], 210$ (6), 156 (9), 155 (100) $\left[\mathrm{M}^{+}-\mathrm{C}_{8} \mathrm{H}_{17},-\mathrm{CO}_{2} \mathrm{CH}_{3}\right), 154$ (14), 39 (18); 
HRMS: $m / z$ calcd. $323.2824\left(\mathrm{C}_{20} \mathrm{H}_{37} \mathrm{NO}_{2}\right)$, found 323.2836, $\Delta=1.2 \mathrm{mmu}$.

2-Aminomethyl-2-octyldecan-1-ol $\left(\mathrm{C}_{19} \mathrm{H}_{41} \mathrm{NO}\right) 5.92 \mathrm{~g}$ $\mathrm{LiAlH}_{4}$ (156 mmol, 1.3 equiv.) was disperged under argon in $100 \mathrm{~cm}^{3}$ anhydrous tert-butyl methyl ether, diluted with $50 \mathrm{~cm}^{3}$ tert-butyl methyl ether, treated dropwise with stirring and ice cooling with $38.8 \mathrm{~g}$ 2-cyano-2-octyldecanoic acid methylester $(120 \mathrm{mmol})$ in $50 \mathrm{~cm}^{3}$ tert-butyl methyl ether, treated with further $400 \mathrm{mg} \mathrm{\textrm {LAlH } _ { 4 }}(11 \mathrm{mmol})$, refluxed for $1 \mathrm{~h}$, stirred at room temperature for $16 \mathrm{~h}$, treated cautiously dropwise and with vigorous stirring and ice cooling with $6 \mathrm{~cm}^{3}$ distilled water, $6 \mathrm{~cm}^{3} 2 \mathrm{~N}$ aqueous $\mathrm{NaOH}$, and $20 \mathrm{~cm}^{3}$ distilled water, stirred for $2 \mathrm{~h}$ and filtered. The finely powdered solid was three times refluxed with $50 \mathrm{~cm}^{3}$ each tertbutyl methyl ether (30 min) and discarded. The combined organic phases were washed with distilled water, dried with magnesium sulfate, and distilled with Kugelrohr in medium vacuum. Yield $24.5 \mathrm{~g}(81.7 \mathrm{mmol}, 68 \%)$ colorless liquid; b.p.: $205-225^{\circ} \mathrm{C}\left(1 \times 10^{-3}-2 \times 10^{-3} \mathrm{mbar}\right)$; IR (ATR): $\bar{v}=3368(\mathrm{w}, \mathrm{br}), 3300(\mathrm{w}, \mathrm{br}), 1596(\mathrm{w}), 1466(\mathrm{~m}), 1378$ (w), $1051(\mathrm{~m}), 721(\mathrm{w}) \mathrm{cm}^{-1} ;{ }^{1} \mathrm{H}$ NMR $\left(600 \mathrm{MHz}, \mathrm{CDCl}_{3}\right)$ : $\delta=0.88\left(\mathrm{t}, 6 \mathrm{H},{ }^{3} \mathrm{~J}=7.0 \mathrm{~Hz},-\mathrm{CH}_{3}\right), 1.26\left(\mathrm{~m}, 28 \mathrm{H},-\mathrm{CH}_{2}\right)$, $2.77\left(\mathrm{~s}, 2 \mathrm{H},-\mathrm{CH}_{2}-\mathrm{NH}_{2}\right), 3.56\left(\mathrm{~s}, 2 \mathrm{H},-\mathrm{CH}_{2}-\mathrm{OH}\right) \mathrm{ppm} ;{ }^{13} \mathrm{C}$ $\operatorname{NMR}\left(150 \mathrm{MHz}, \mathrm{CDCl}_{3}\right): \delta=14.1,22.7,23.0,29.3,29.6$, $30.6,31.9,50.1,71.5 \mathrm{ppm}$.

2,7-Bis(2-ethyl-2-hydroxymethylbutyl)benzo[Imn][3,8]phenanthroline-1,3,6,8-tetraone $\left(4 \mathrm{a}, \mathrm{C}_{28} \mathrm{H}_{34} \mathrm{~N}_{2} \mathrm{O}_{6}\right) 410 \mathrm{mg}$ Isochromeno[6,5,4-def] isochromene-1,6,8-tetraone $(1.53 \mathrm{mmol}), 600 \mathrm{mg}$ 2-aminomethyl-2-ethylbutane-1-ol ( $4.60 \mathrm{mmol}$ ), and $25 \mathrm{~cm}^{3} \mathrm{DMF}$ under nitrogen were refluxed at $100{ }^{\circ} \mathrm{C}$ for $2 \mathrm{~h}$ (color change to red), allowed to cool, treated cautiously with ice cooling with $50 \mathrm{~cm}^{3} 2 \mathrm{~N}$ aqueous $\mathrm{HCl}$, collected by vacuum filtration, washed with a small amount of distilled water, dried at $80{ }^{\circ} \mathrm{C}$ in air, dispersed in a small amount of methanol, refluxed with $10 \%$ aqueous $\mathrm{K}_{2} \mathrm{CO}_{3}$, collected by vacuum filtration, washed with metha$\mathrm{nol} /$ water $1: 1$, and dried at $80{ }^{\circ} \mathrm{C}$ in air. Yield $202 \mathrm{mg} \mathrm{(26 \% )}$ slightly rose solid; m.p.: $255-258{ }^{\circ} \mathrm{C}$; IR (ATR): $\bar{\nu}=3550$ (s), $3508(\mathrm{~m}), 2967(\mathrm{~s}), 2883(\mathrm{~m}), 1702(\mathrm{~s}), 1657(\mathrm{~s}), 1580$ (m), $1549(\mathrm{w}), 1454(\mathrm{~m}), 1428(\mathrm{w}), 1372(\mathrm{~m}), 1329(\mathrm{~s}), 1247$ (m), 1168 (w), $1105(\mathrm{w}), 1030$ (w), $1001(\mathrm{w}), 889(\mathrm{w}), 772$ (m) $\mathrm{cm}^{-1} ;{ }^{1} \mathrm{H} \mathrm{NMR}\left(\mathrm{CDCl}_{3}, 600 \mathrm{MHz}\right): \delta=0.94(\mathrm{t}, 12 \mathrm{H}$, $\left.{ }^{3} J=7.5 \mathrm{~Hz},-\mathrm{CH}_{3}\right), 1.32\left(\mathrm{qd}, 4 \mathrm{H},{ }^{3} J=7.5 \mathrm{~Hz},{ }^{2} J=14.7 \mathrm{~Hz}\right.$, $\left.-\mathrm{CH}_{2}-\right), 1.41$ (qd, $4 \mathrm{H},{ }^{3} J=7.5 \mathrm{~Hz},{ }^{2} J=14.9 \mathrm{~Hz},-\mathrm{CH}_{2}-$ ), $3.23\left(\mathrm{~d}, 4 \mathrm{H},{ }^{3} J=7.6 \mathrm{~Hz},-\mathrm{CH}_{2}-\mathrm{OH}\right), 3.62\left(\mathrm{t}, 2 \mathrm{H},{ }^{3} J=7.6 \mathrm{~Hz}\right.$, $\left.-\mathrm{CH}_{2}-\mathrm{OH}\right), 8.79\left(\mathrm{~s}, 4 \mathrm{H}, \mathrm{CH}_{\mathrm{ar}}\right) \mathrm{ppm} ;{ }^{13} \mathrm{C} \mathrm{NMR}\left(\mathrm{CDCl}_{3}\right.$, $600 \mathrm{MHz}): \delta=7.4,23.7,43.1,43.7,65.2,126.5,126.6$, 131.6, $164.3 \mathrm{ppm}$; UV/Vis $\left(\mathrm{CHCl}_{3}\right): \lambda_{\max }=383,362$, $344 \mathrm{~nm}$; MS (ESI): $m / z(\%)=641(82)\left[\mathrm{M}^{+}+{ }^{35} \mathrm{Cl}\right], 605$ (47) $\left[\mathrm{M}^{+}-\mathrm{H}^{+}\right.$]; HRMS/ESI: $m / z$ calcd. $494.2417\left(\mathrm{C}_{28} \mathrm{H}_{34} \mathrm{~N}_{2} \mathrm{O}_{6}\right)$, found 494.2429, $\Delta=1.2 \mathrm{mmu}$.
2,7-Bis(2-hydroxymethyl-2-propylpentyl)benzo[Imn][3,8]phenanthroline-1,3,6,8-tetraone $\left(\mathbf{4 b}, \mathrm{C}_{32} \mathrm{H}_{42} \mathrm{~N}_{2} \mathrm{O}_{6}\right) 655 \mathrm{mg}$ Isochromeno[6,5,4-def] isochromene-1,3,6,8-tetraone (2.45 mmol), $1.17 \mathrm{~g} \mathrm{2-aminomethyl-2-propylpentane-1-ol}$ (7.34 mmol), and $75 \mathrm{~cm}^{3}$ DMF were allowed to react and purified analogously to 2,7-bis(2-ethyl-2-hydroxymethylbutyl)benzo[lmn][3,8]phenanthroline-1,3,6,8-tetraone (4a). Yield $750 \mathrm{mg}(56 \%)$ slightly rose solid; m.p.: $199-201{ }^{\circ} \mathrm{C}$; IR (ATR): $\bar{v}=3478$ (s), 2953 (s), 2928 (m), 2871 (m), 1698 (s), 1642 (s), $1582(\mathrm{~m}), 1458$ (m), 1433 (m), 1374 (m), 1330 (s), $1244(\mathrm{~m}), 1202(\mathrm{~m}), 1161(\mathrm{w}), 1094(\mathrm{~m}), 1039(\mathrm{w})$, $1016(\mathrm{~m}), 975$ (w), 890 (w), 860 (w), $776(\mathrm{~m}), 720$ (w), $662(\mathrm{w}) \mathrm{cm}^{-1} ;{ }^{1} \mathrm{H}$ NMR $\left(300 \mathrm{MHz}, \mathrm{CDCl}_{3}\right): \delta=0.94(\mathrm{t}$, $\left.12 \mathrm{H},{ }^{3} \mathrm{~J}=7.3 \mathrm{~Hz},-\mathrm{CH}_{3}\right), 1.34\left(\mathrm{~m}, 12 \mathrm{H},-\mathrm{CH}_{2}\right), 1.50(\mathrm{~m}$, $\left.4 \mathrm{H},-\mathrm{CH}_{2}\right), 3.20\left(\mathrm{~d}, 4 \mathrm{H},{ }^{3} \mathrm{~J}=7.6 \mathrm{~Hz}-\mathrm{CH}_{2}-\mathrm{OH}\right), 3.70(\mathrm{t}$, $\left.2 \mathrm{H},{ }^{3} \mathrm{~J}=7.6 \mathrm{~Hz},-\mathrm{CH}_{2}-\mathrm{OH}\right), 4.20\left(\mathrm{~s}, 4 \mathrm{H},-\mathrm{CH}_{2}-\mathrm{NR}_{2}\right), 8.79$ (s, $4 \mathrm{H}, \mathrm{CH}_{\mathrm{ar}}$ ) ppm; ${ }^{13} \mathrm{C} \mathrm{NMR}\left(600 \mathrm{MHz}, \mathrm{CDCl}_{3}\right): \delta=14.96$, $16.28,34.38,43.25,43.99,65.68,126.5,131.6,164.3 \mathrm{ppm}$; UV/Vis $\left(\mathrm{CHCl}_{3}\right): \lambda_{\text {max }}(\varepsilon)=383(26,600), 362(22,000)$, $344(13,400) \mathrm{nm}\left(\mathrm{dm}^{3} \mathrm{~mol}^{-1} \mathrm{~cm}^{-1}\right) ; \mathrm{MS}\left(\mathrm{DEI}^{+}, 70 \mathrm{eV}\right): \mathrm{m} / \mathrm{z}$ $(\%)=550(15)\left[\mathrm{M}^{+}\right], 520(100)\left[\mathrm{M}^{+}-\mathrm{CH}_{3} \mathrm{O}\right], 422(7), 410$ (12), 409 (53), 294 (9), 281 (13), 268 (6).

2,7-Bis(2-butyl-2-hydroxymethylhexyl)benzo[Imn][3,8]phenanthrolin-1,3,6,8-tetraone $\left(4 \mathrm{c}, \mathrm{C}_{40} \mathrm{H}_{42} \mathrm{~N}_{2} \mathrm{O}_{6}\right) 1.31 \mathrm{~g}$ Isochromeno[6,5,4-def] isochromene-1,3,6,8-tetraone (4.89 mmol), $2.75 \mathrm{~g} \mathrm{2-aminomethyl-2-butylhexane-1-ol}$ ( $14.7 \mathrm{mmol}$ ), and $70 \mathrm{~cm}^{3}$ DMF were allowed to react and purified analogously to 2,7-bis(2-ethyl-2-hydroxymethylbutyl)benzo[ $[\mathrm{lmn}][3,8]$ phenanthroline-1,3,6,8-tetraone (4a). Yield $985 \mathrm{mg}$ (1.62 mmol, 33\%) colorless, shiny solid; m.p.: 232-234 ${ }^{\circ} \mathrm{C}$; IR (ATR): $\bar{v}=3480$ (s), 2953 (s), 2930 (s), 2864 (m), 1698 (s), $1646(\mathrm{~s}), 1581(\mathrm{~m}), 1459(\mathrm{~m}), 1432$ (m), 1367 (m), $1330(\mathrm{~s}), 1244(\mathrm{~s}), 1199(\mathrm{w}), 1150(\mathrm{w}), 1099(\mathrm{w}), 1024$ (m), $884(\mathrm{w}), 865(\mathrm{w}), 776(\mathrm{w}), 720(\mathrm{w}), 660(\mathrm{w}) \mathrm{cm}^{-1}$; ${ }^{1} \mathrm{H} \mathrm{NMR}\left(\mathrm{CDCl}_{3}, 600 \mathrm{MHz}\right): \delta=0.92\left(\mathrm{t}, 12 \mathrm{H},{ }^{3} \mathrm{~J}=7.1 \mathrm{~Hz}\right.$, $\left.-\mathrm{CH}_{3}\right), 1.22-1.33\left(\mathrm{~m}, 20 \mathrm{H},-\mathrm{CH}_{2}-\right), 1.38-1.46(\mathrm{~m}, 4 \mathrm{H},-$ $\left.\mathrm{CH}_{2}-\right), 3.21\left(\mathrm{~d}, 4 \mathrm{H},{ }^{3} \mathrm{~J}=7.6 \mathrm{~Hz},-\mathrm{CH}_{2}-\mathrm{OH}\right), 3.67(\mathrm{t}, 2 \mathrm{H}$, $\left.{ }^{3} \mathrm{~J}=7.6 \mathrm{~Hz},-\mathrm{CH}_{2}-\mathrm{OH}\right), 4.21\left(\mathrm{~s}, 4 \mathrm{H},-\mathrm{CH}_{2}-\mathrm{NR}_{2}\right), 8.79$ (s, $\left.4 \mathrm{H}, \mathrm{CH}_{\mathrm{ar}}\right) \mathrm{ppm} ;{ }^{13} \mathrm{C} \mathrm{NMR}\left(\mathrm{CDCl}_{3}, 600 \mathrm{MHz}\right): \delta=14.07$, 23.60, 25.1, 31.65, 43.02, 43.98, 65.70, 126.51, 131.58, $164.25 \mathrm{ppm}$; MS (ESI): $\mathrm{m} / \mathrm{z}(\%)=641(82)\left[\mathrm{M}^{+}+{ }^{35} \mathrm{Cl}\right], 605$ (47) $\left[\mathrm{M}^{+}-\mathrm{H}\right]$; UV/Vis $\left(\mathrm{CHCl}_{3}\right): \lambda_{\max }(\varepsilon)=383(26,600), 362$ $(21,900), 344(13,400) \mathrm{nm}\left(\mathrm{dm}^{3} \mathrm{~mol}^{-1} \mathrm{~cm}^{-1}\right)$.

Bis(2-butyl-2-hydroxymethylhexyl)benzo[Imn][3,8]phenanthroline-1,3,6,8-tetraone (4d, $\left.\mathrm{C}_{40} \mathrm{H}_{58} \mathrm{~N}_{2} \mathrm{O}_{6}\right) 1.31 \mathrm{~g}$ Isochromeno[6,5,4-def]isochromene-1,3,6,8-tetraone $\mathbf{1 3}$ (4.89 mmol), $3.16 \mathrm{~g}$ 2-aminomethyl-2-pentylheptan-1-ol (14.7 mmol), and $75 \mathrm{~cm}^{3}$ DMF were allowed to react and purified analogously to 2,7-bis(2-ethyl-2-hydroxymethylbutyl)benzo[lmn][3,8]phenanthroline-1,3,6,8-tetraone (4a). Yield $575 \mathrm{mg}(867 \mu \mathrm{mol}, 18 \%)$ colorless, shiny solid; m.p.: 
226-229 ${ }^{\circ} \mathrm{C}$; IR (ATR): $\bar{v}=3486$ (s), 2930 (s), 2862 (m), 1698 (s), 1644 (s), 1581 (m), 1460 (m), 1431 (w), 1413 (w), 1369 (w), 1330 (s), 1242 (m), 1209 (w), 1191 (w), 1150 (w), 1104 (w), 1058 (w), 1026 (m), 890 (w) 863 (vw), 778 (w) 719 (w) $662(\mathrm{w}) \mathrm{cm}^{-1}$; ${ }^{1} \mathrm{H} \mathrm{NMR}\left(\mathrm{CDCl}_{3}, 600 \mathrm{MHz}\right)$ : $\delta=0.92\left(\mathrm{t}, 12 \mathrm{H},{ }^{3} \mathrm{~J}=7.2 \mathrm{~Hz},-\mathrm{CH}_{3}\right), 1.19-1.37(\mathrm{~m}, 28 \mathrm{H},-$ $\left.\mathrm{CH}_{2}-\right)$, 1.38-1.48 (m, 4H, $\left.-\mathrm{CH}_{2}-\right), 3.20\left(\mathrm{~d}, 4 \mathrm{H},{ }^{3} \mathrm{~J}=7.6 \mathrm{~Hz}\right.$, $\left.-\mathrm{CH}_{2}-\mathrm{OH}\right), 3.65\left(\mathrm{t}, 2 \mathrm{H},{ }^{3} \mathrm{~J}=7.6 \mathrm{~Hz},-\mathrm{CH}_{2}-\mathrm{OH}\right), 8.79(\mathrm{~s}, 4 \mathrm{H}$, $\left.\mathrm{CH}_{\mathrm{ar}}\right) \mathrm{ppm} ;{ }^{13} \mathrm{C} \mathrm{NMR}\left(\mathrm{CDCl}_{3}, 600 \mathrm{MHz}\right): \delta=14.12,22.59$, 31.95, 32.79, 43,10, 65.72, 126.50, 131.57, 164.24 ppm; UV/Vis $\left(\mathrm{CHCl}_{3}\right): \lambda_{\max }(\varepsilon)=383(26,600), 362(22,000), 344$ $(13,800) \mathrm{nm}\left(\mathrm{dm}^{3} \mathrm{~mol}^{-1} \mathrm{~cm}^{-1}\right)$; MS (ESI): $\mathrm{m} / z(\%)=697$ (68) $\left[\mathrm{M}^{+}+{ }^{35} \mathrm{Cl}\right], 661(47)\left[\mathrm{M}^{+}-\mathrm{H}\right]$.

2,7-Bis(2-hydroxymethyl-2-octyldecyl)benzo[Imn][3,8]phenanthroline-1,3,6,8-tetraone $\left(4 \mathrm{e}, \mathrm{C}_{52} \mathrm{H}_{81} \mathrm{~N}_{2} \mathrm{O}_{5}\right) 1.50 \mathrm{~g}$ Isochromeno[6,5,4-def] is ochromene-1,3,6,8-tetraone (5.59 mmol), $5.30 \mathrm{~g}$ 2-aminomethyl-2-octyldecane-1-ol (16.8 $\mathrm{mmol})$, and $170 \mathrm{~cm}^{3} \mathrm{DMF}$ were allowed to react and purified analogously to 2,7-bis(2-ethyl-2-hydroxymethylbutyl)benzo[lmn][3,8]phenanthroline-1,3,6,8-tetraone (4a) and recrystallised two times from chloroform and purified by column separation (silica gel 60, chloroform/acetic acid 50:1). Yield $1.74 \mathrm{~g}$ (2.09 mmol, 37\%) slightly rose, shiny solid; m.p.: $176-178{ }^{\circ} \mathrm{C} ; R_{f}=0.5$ (silica gel, cloroform/acetic acid 50:1); IR (ATR): $\bar{v}=3481$ (s), 2956 (m), 2921 (s), 2852 (s), 1699 (s), 1645 (s), 1580 (s), 1460 (s), 1432 (w), 1415 (w), 1387 (w), 1370 (w), 1331 (s), 1255 (w), 1245 (m), 1191 (w), 1152 (w), $1112(\mathrm{w}), 1094(\mathrm{w})$, 1027 (w), 975 (w), 891 (w), 865 (w), 815 (w), 779 (w), 720 (w) $\mathrm{cm}^{-1} ;{ }^{1} \mathrm{H} \mathrm{NMR}\left(600 \mathrm{MHz}, \mathrm{CDCl}_{3}\right): \delta=0.88(\mathrm{t}, 12 \mathrm{H}$, $\left.{ }^{3} J=7.0 \mathrm{~Hz},-\mathrm{CH}_{3}\right), 1.20-1.33\left(\mathrm{~m}, 50 \mathrm{H},-\mathrm{CH}_{2}-\right), 1.36-1.45$ (m, 4H, $-\mathrm{CH}_{2}-$ ), 1.54-1.60 (m, 2H, $-\mathrm{CH}_{2}-$ ), $3.20(\mathrm{~s}, 4 \mathrm{H}$, $-\mathrm{CH}_{2}-\mathrm{NR}_{2}$ ), 3.66 (s, br, 2H, $\left.-\mathrm{OH}\right), 8.79$ (s, 4H, $\mathrm{CH}_{\mathrm{ar}}$ ) ppm; ${ }^{13} \mathrm{C}$ NMR $\left(600 \mathrm{MHz}, \mathrm{CDCl}_{3}\right): \delta=14.11,22.66,22.89$, $29.31,29.51,29.53,30.55,30.57,31.87,31.95,31.98$, 43.08, 43.97, 65.69, 126.48, 131.56, 164.21, 164.23 ppm; $\mathrm{UV} / \mathrm{V}$ is $\left(\mathrm{CHCl}_{3}\right): \lambda_{\max }(\varepsilon)=383(26,900), 362(22,300), 344$ $(14,000) \mathrm{nm}\left(\mathrm{dm}^{3} \mathrm{~mol}^{-1} \mathrm{~cm}^{-1}\right)$; MS (ESI): $\mathrm{m} / z(\%)=865.6$ (100) $\left[\mathrm{M}^{+}+{ }^{35} \mathrm{Cl}\right], 830.6$ (44) $\left[\mathrm{M}^{+}-\mathrm{H}\right]$; HRMS: $m / z$ calcd. $831.6173\left(\mathrm{C}_{52} \mathrm{H}_{81} \mathrm{~N}_{2} \mathrm{O}_{5}\right)$, found 831.6290, $\Delta=1.1 \mathrm{mmu}$.

\section{$N, N^{\prime}$-Bis(1-hexylheptyl)quaterrylene-3,4,13,14-tetracarbox-} ylic acid 3,4:13,14-diimide $\left(\mathbf{1 3}, \mathrm{C}_{70} \mathrm{H}_{70} \mathrm{~N}_{2} \mathbf{O}_{4}\right)$ [31] $200 \mathrm{mg}$ 9,9'-Bis[N-(1-hexylheptyl)perylene-3,4-dicarboximide] (196 mmol) and $1.26 \mathrm{~g}$ potassium carbonate $(9.31 \mathrm{mmol})$ were suspended in $1.8 \mathrm{~cm}^{3}$ ethanolamine heated with stirring at $160{ }^{\circ} \mathrm{C}$ for $4 \mathrm{~h}$, allowed to cool, treated with $10 \mathrm{~cm}^{3}$ methanol, collected by vacuum filtration, washed with plenty of water, dried at $100{ }^{\circ} \mathrm{C}$ in air for $16 \mathrm{~h}$, purified by column separation ( silica gel, dichloromethane), dissolved in a small amount of dichloromethane, precipitated with plenty of methanol, and dried at $100{ }^{\circ} \mathrm{C}$ in air for $16 \mathrm{~h}$. Yield
$96 \mathrm{mg}\left(48 \%\right.$ ) blue solid; m.p.: $>250{ }^{\circ} \mathrm{C} ; R_{f}=0.07$ (silica gel/ $\mathrm{CH}_{2} \mathrm{Cl}_{2}$ ); IR (ATR): $\bar{v}=2920$ (s), 2851 (s), 1688 (s), 1645 (s), $1595(\mathrm{~m}), 1571$ (s), 1502 (m), 14561404 (m), 1372 (w), 1344 (s), 1284 (m) 1219 (w), 1171 (w), 1104 (w), 1047 (w), 836 (w) 804 (m), 745 (m), 669 (w) $\mathrm{cm}^{-1}$; ${ }^{1} \mathrm{H}$ NMR $\left(\mathrm{CDCl}_{3}, 600 \mathrm{MHz}\right): \delta=0.85-0.95\left(\mathrm{t}, \mathrm{br}, 12 \mathrm{H}-\mathrm{CH}_{3}\right), 1.14$ (m, 32H, $-\mathrm{CH}_{2}$ ), 2.00 (m, br, 4H, $\left.\mathrm{R}_{2} \mathrm{NCH}-\mathrm{CH}_{2}-\mathrm{R}\right), 2.30(\mathrm{~m}$, $\left.4 \mathrm{H}, \mathrm{R}_{2} \mathrm{NCH}-\mathrm{CH}_{2}-\mathrm{R}\right), 5.19\left(\mathrm{~m}, 1 \mathrm{H}, \mathrm{R}_{2} \mathrm{NCH}-\right), 7.72-7.85$ (m, $\left.12 \mathrm{H}, \mathrm{CH}_{\mathrm{ar}}\right), 8.23$ (s, 4H, $\left.\mathrm{CH}_{\mathrm{ar}}\right) \mathrm{ppm} ;{ }^{13} \mathrm{C} \mathrm{NMR}\left(\mathrm{CDCl}_{3}\right.$, $150 \mathrm{MHz}): \delta=14.4,2.9,27.5,29.6,29.9,31.2,32.1,32.7$, 54.9, 120.4, 122.4, 123.8, 125.8, 127.3, 127.9, 129.2, 129.9, 131.3, 135.3, $164.8 \mathrm{ppm}$; UV/Vis: $\lambda_{\max }\left(E_{r e l}\right)=762(1.00)$, 694 (sh., 0.18), 377 nm (sh., 0.09); MS (ESI): $m / z=1002.5$ $\left[\mathrm{M}^{+}\right]$.

$N, N^{\prime \prime}$-Bis(1-hexylheptyl)-N'-(2-hydroxymethyl-2-octyldecyl)benzoperylene- $1^{\prime}, 2^{\prime}, 3,4,9,10$-hexacarboxylic acid $1^{\prime}, 2^{\prime}: 3,4: 9,10$-trisimide $\left(\mathbf{1 6}, \mathrm{C}_{73} \mathrm{H}_{\mathbf{9 9}} \mathrm{N}_{3} \mathbf{O}_{7}\right) 500 \mathrm{mg} \mathrm{N}, N^{\prime}$-Bis $(1-$ hexylheptyl)benzo $[g, h, i]$ perylene-2,3,8,9,11,12-hexacarboxylic acid 2,3;8,9-bisimide-11,12-anhydride (590 $\mu \mathrm{mol})$, $609 \mathrm{mg}$ dicyclohexyl carbodiimide $(295 \mu \mathrm{mol})$, and $931 \mathrm{mg}$ 2-aminomethyl-2-octyldecane-1-ol (295 $\mu \mathrm{mol})$ were dissolved in $18 \mathrm{~cm}^{3}$ chloroform, treated with three drops of trifluoroacetic acid, refluxed for $18 \mathrm{~h}$, allowed to cool, treated with $80 \mathrm{~cm}^{3}$ distilled water, stirred at room temperature $(3 \mathrm{~h})$, diluted with $350 \mathrm{~cm}^{3}$ chloroform, extracted three times with $300 \mathrm{~cm}^{3}$ each $2 \mathrm{~N}$ aqueous $\mathrm{HCl}$, dried over magnesium sulfate, evaporated, dissolved in a small amount of chloroform, precipitated with plenty of methanol, collected by vacuum filtration, purified by column separation (silica gel, toluene to remove the starting material) and a second column separation (silica gel, isohexane to remove aliphatic by-product and elution with toluene for the main fraction), dissolved in a small amount of chloroform and precipitated with methanol, collected by vacuum filtration, and dried at $80{ }^{\circ} \mathrm{C}$ in air. Yield $137 \mathrm{mg}(21 \%)$ yellow solid; m.p.: 289$292{ }^{\circ} \mathrm{C} ; R_{f}=0.5$ (toluene); IR (ATR): $\bar{v}=3551(\mathrm{~m}), 2955(\mathrm{~s})$, 2924 (s), 2855 (s), 1766 (w), 1707 (m), 1663 (m), 1625 (w), 1596 (w), 1523 (w), 1457 (w), 1414 (w), 1397 (w), 1364 (w), 1316 (m), 1239 (w), 1175 (w), 1103 (w), 945 (w), 845 (w), $812(\mathrm{w}), 764(\mathrm{w}), 747(\mathrm{w}) \mathrm{cm}^{-1} ;{ }^{1} \mathrm{H}$ NMR $(600 \mathrm{MHz}$, $\left.\mathrm{CDCl}_{3}\right): \delta=0.84\left(\mathrm{t}, 12 \mathrm{H},{ }^{3} \mathrm{~J}=7.0 \mathrm{~Hz},-\mathrm{CH}_{3}\right), 0.89(\mathrm{t}, 6 \mathrm{H}$, $\left.{ }^{3} \mathrm{~J}=6.9 \mathrm{~Hz},-\mathrm{CH}_{3}\right), 1.23-1.58\left(\mathrm{~m}, 56 \mathrm{H},-\mathrm{CH}_{2}\right), 2.01(\mathrm{~m}, \mathrm{br}$, $4 \mathrm{H}, \mathrm{NR}_{2}-\mathrm{CH}-\mathrm{CH}_{2}$ ), 2.38 (m, br, 4H, NR $-\mathrm{CH}-\mathrm{CH}_{2}$ ), 3.39 (s, 2H, $\left.-\mathrm{CH}_{2}-\mathrm{OH}\right), 3.73$ (s, br, $\left.1 \mathrm{H},-\mathrm{CH}_{2}-\mathrm{OH}\right), 3.93$ (s, 2H, $-\mathrm{CH}_{2}-\mathrm{NR}_{2}$ ), 9.10 (s, br, $2 \mathrm{H}, \mathrm{CH}_{\mathrm{ar}}$ ), 9.18 (s, br, $2 \mathrm{H}, \mathrm{CH}_{\mathrm{ar}}$ ), 10.22 (s, br, $2 \mathrm{H}, \mathrm{CH}_{\mathrm{ar}}$ ) ppm; ${ }^{13} \mathrm{C} \mathrm{NMR}\left(150 \mathrm{MHz}, \mathrm{CDCl}_{3}\right)$ : $\delta=14.0,22.7,27.1,29.3,29.4,29.7,30.6,31.8,31.9$, 42.9, 55.4, 65.5, 122.9, 123.8, 124.4, 127.0, 127.4, 132.8, $169.6 \mathrm{ppm}$; UV/Vis $\left(\mathrm{CHCl}_{3}\right): \lambda_{\max }(\varepsilon)=379(43,000), 411$ $(16,000), 436(39,000), 466(61,000) \mathrm{nm}\left(\mathrm{dm}^{3} \mathrm{~mol}^{-1} \mathrm{~cm}^{-1}\right)$; Fluorescence $\left(\mathrm{CHCl}_{3}\right): \lambda_{\max }=475,509 \mathrm{~nm}$; Fluorescence quantum yield $\left(\mathrm{CHCl}_{3}, E=0.0338 \mathrm{~cm}^{-1}, \lambda_{\text {exc }}=435 \mathrm{~nm}\right.$, 
reference perylene-3,4,9,10-tetracarboxylic acid tetramethyl ester with $\Phi=100 \%): 32 \%$; MS (DEI $\left.{ }^{+}, 70 \mathrm{eV}\right): \mathrm{m} / z$ $(\%)=1132.1$ (29), 1131.1 (29), 1130.1 (64), 1129.1 (83) $\left[\mathrm{M}^{+}\right], 1116.1,1099.1$ (46), 950.1 (13), 949.1 (37), 948.1 (61), 917.1 (46), 861.1 (27), 860.1 (21), 737.1 (46), 735.1 (38), 680.0 (49), 679.0 (81), 678.0 (42), 666.0 (25), 509.9 (11), 499.0 (19), 498.0 (58), 496.9 (100), 495.9 (74), 483.9 (58), 482.9 (34), 414.0 (18), 111.2 (17), 83.2 (35), 69.2 (47); HRMS/ESI: $m / z$ calcd. $1131.7640\left(\mathrm{C}_{73} \mathrm{H}_{101} \mathrm{~N}_{3} \mathrm{O}_{7}\right)$, found $1131.7643, \Delta=0.3 \mathrm{mmu}$.

2,7-Bis(2-ethyl-2-hydroxymethylbutyl)-3,6,8-trioxo-1,2,3,6,7,8-hexahydrobenzo[ $/ \mathrm{mn}][3,8]$ phenanthrolin-1-ol radical anion tetrabutylammonium salt $(5 \mathrm{a}$, $\left.\mathrm{C}_{28} \mathrm{H}_{34} \mathrm{~N}_{2} \mathrm{O}_{6} \cdot \mathrm{C}_{16} \mathrm{H}_{36} \mathrm{~N}\right) 122 \mathrm{mg}$ 2,7-Bis(2-ethyl-2-hydroxymethylbutyl)benzo[ $[\mathrm{Imn}][3,8]$ phenanthroline-1,3,6,8-tetraone $(\mathbf{4 a}, 240 \mu \mathrm{mol})$ under argon was dispersed in $0.5 \mathrm{~cm}^{3}$ degassed ethanol, treated with $1 \mathrm{~cm}^{3}$ degassed distilled water and $1 \mathrm{~cm}^{3} \mathrm{DBU}$, heated at $45^{\circ} \mathrm{C}$, treated with $1 \mathrm{~cm}^{3}$ hydroxyacetone $(15 \mathrm{mmol})$, stirred for $10 \mathrm{~min}$, treated with $1.0 \mathrm{~g}$ tetrabutylammonium bromide $(3.1 \mathrm{mmol})$ in $1.5 \mathrm{~g}$ degassed distilled water, diluted with $10 \mathrm{~cm}^{3}$ degassed distilled water, stirred at $0{ }^{\circ} \mathrm{C}$ for $10 \mathrm{~min}$, collected by vacuum filtration under argon, washed with degassed distilled water until colorless washings, dried in medium vacuum and then in a countercurrent of nitrogen over phosphorous pentoxide. Yield $38 \mathrm{mg}(21 \%)$ brownish black solid; m.p.: $>300{ }^{\circ} \mathrm{C}$; IR (ATR): $\bar{v}=3332$ (m, br), 2959 (s), 2875 (m), 1632 (s), 1580 (s), 1558 (s), $1520(\mathrm{~s}), 1458(\mathrm{~m}), 1376(\mathrm{~m}), 1298(\mathrm{~m}), 1146$ (w), $1068(\mathrm{~m}), 876(\mathrm{w}), 798(\mathrm{w}), 756(\mathrm{w}) \mathrm{cm}^{-1}$; UV/Vis (acetone): $\lambda_{\max }\left(E_{\text {rel }}\right)=477$ (1.00), $611(0.24), 686(0.06)$, $761(0.14) \mathrm{nm}$.

2,7-Bis(2-hydroxymethyl-2-propylpentyl)-3,6,8-trioxo-1,2,3,6,7,8-hexahydrobenzo[ $[\mathrm{mn}][3,8]$ phenanth-

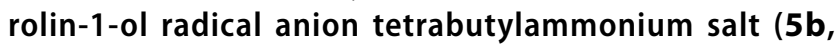
$\left.\mathrm{C}_{32} \mathrm{H}_{42} \mathrm{~N}_{2} \mathrm{O}_{6} \cdot \mathrm{C}_{16} \mathrm{H}_{36} \mathrm{~N}\right) 132 \mathrm{mg}$ 2,7-Bis(2-hydroxymethyl2-propylpentyl)benzo[ $[\mathrm{mn}][3,8]$ phenanthroline-1,3,6,8tetraone $(\mathbf{4 b}, 0.24 \mathrm{mmol})$ was allowed to react and purified as was described for 2,7-bis(2-ethyl-2-hydroxymethylbutyl)3,6,8-trioxo-1,2,3,6,7,8-hexahydrobenzo[ $l m n][3,8]$ phenanthrolin-1-ol radical anion tetrabutylammonium salt (5a). Yield $97 \mathrm{mg}(0.11 \mathrm{mmol}, 48 \%)$ brownish black solid; m.p.: $>300^{\circ} \mathrm{C}$; IR (ATR): $\bar{v}=3317$ (m, br), 2958 (s), 2931 (m), 2872 (s), 1621 (s), 1577 (s), 1555 (m), $1516(\mathrm{~s}), 1488$ (w), $1461(\mathrm{~m}), 1435$ (w), 1379 (w), 1324 (m), $1296(\mathrm{~m}), 1232$ (w), $1204(\mathrm{w}), 1150(\mathrm{w}), 1103(\mathrm{w}), 1053(\mathrm{w}), 1010(\mathrm{w}), 880$ (w), 853 (w), $812(\mathrm{w}), 744(\mathrm{w}) \mathrm{cm}^{-1}$; ${ }^{1} \mathrm{H}$ NMR (400 MHz, acetone- $\left.d_{6}\right): \delta=0.97\left(\mathrm{t}, 12 \mathrm{H},{ }^{3} J=7 \mathrm{~Hz}, \mathrm{R}_{3} \mathrm{~N}-\left(\mathrm{CH}_{2}\right)_{3}-\mathrm{CH}_{3}\right)$, $1.42\left(\mathrm{~m}, 8 \mathrm{H}, \mathrm{R}_{3} \mathrm{~N}-\left(\mathrm{CH}_{2}\right)_{2}-\mathrm{CH}_{2}-\mathrm{CH}_{3}\right), 1.80\left(\mathrm{q}, \mathrm{br}, 8 \mathrm{H}, \mathrm{R}_{3} \mathrm{~N}-\right.$ $\left.\mathrm{CH}_{2}-\mathrm{CH}_{2}-\mathrm{CH}_{2}-\mathrm{CH}_{3}\right), 3.42\left(\mathrm{t}, 8 \mathrm{H},{ }^{3} \mathrm{~J}=8 \mathrm{~Hz}, \mathrm{R}_{3} \mathrm{~N}-\mathrm{CH}_{2}-\right.$ $\left(\mathrm{CH}_{2}\right)_{2}-\mathrm{CH}_{3}$ ) ppm; ESR (solid state): $g=2.0043$; ESR (acetone): $g=2.0042$; UV/Vis (acetone): $\lambda_{\max }\left(E_{\text {rel }}\right)=477$ (1.00),
611 (0.13), 686 (0.08), 761 (0.02) nm; MS (FAB $\left.{ }^{-}\right): m / z$ $(\%)=550.3(100)\left[\mathrm{M}^{-}\left(\mathrm{C}_{32} \mathrm{H}_{42} \mathrm{~N}_{2} \mathrm{O}_{6}^{-}\right)\right]$; HRMS: $\mathrm{m} / z$ calcd. $550.3048\left(\mathrm{C}_{32} \mathrm{H}_{42} \mathrm{~N}_{2} \mathrm{O}_{6}{ }^{-}\right)$, found 550.3063, $\Delta=1.5 \mathrm{mmu}$.

2,7-Bis(2-butyl-2-hydroxymethylhexyl)-3,6,8-trioxo-1,2,3,6,7,8-hexahydrobenzo[Imn][3,8]phenanthrolin-1-ol radical anion tetrabutylammonium salt $(5 \mathrm{C}$, $\left.\mathrm{C}_{40} \mathrm{H}_{42} \mathrm{~N}_{2} \mathrm{O}_{6} \cdot \mathrm{C}_{16} \mathrm{H}_{36} \mathrm{~N}\right) 146 \mathrm{mg}$ 2,7-Bis(2-butyl-2-hydroxymethylhexyl)benzo[ $[\mathrm{mn}][3,8]$ phenanthroline-1,3,6,8-tetraone $(\mathbf{4 c}, 0.24 \mathbf{m m o l})$ was allowed to react and purified as was described for 2,7-bis(2-ethyl-2-hydroxymethylbutyl)-3,6,8trioxo-1,2,3,6,7,8-hexahydrobenzo[ $[\mathrm{mn}][3,8]$ phenanthrolin-1-ol radical anion tetrabutylammonium salt (5a). Yield $117 \mathrm{mg}$ (58\%) brownish black powder; m.p.: $>300{ }^{\circ} \mathrm{C}$; IR (ATR): $\bar{v}=3300$ (m, br), 3110 (m, br), 2956 (s), $2929(\mathrm{~s})$, $2872(\mathrm{~s}), 1621(\mathrm{~s}), 1587(\mathrm{w}), 1572(\mathrm{w}), 1556(\mathrm{~m}), 1523(\mathrm{~s})$, $1493(\mathrm{w}), 1463(\mathrm{~m}), 1424(\mathrm{w}), 1400(\mathrm{w}), 1380(\mathrm{w}), 1364$ (w), $1293(\mathrm{~m}), 1196(\mathrm{w}), 1145(\mathrm{w}), 1106(\mathrm{w}), 1066(\mathrm{w})$, $1053(\mathrm{w}), 1026(\mathrm{w}), 984(\mathrm{w}), 935(\mathrm{w}), 879(\mathrm{w}), 815(\mathrm{w}), 743$ (w) $\mathrm{cm}^{-1} ;{ }^{1} \mathrm{H}$ NMR $\left(400 \mathrm{MHz}\right.$, acetone- $\left.d_{6}\right): \delta=0.98(\mathrm{t}, 12 \mathrm{H}$, $\left.{ }^{3} \mathrm{~J}=7 \mathrm{~Hz}, \mathrm{R}_{3} \mathrm{~N}-\left(\mathrm{CH}_{2}\right)_{3}-\mathrm{CH}_{3}\right), 1.43\left(\mathrm{~m}, 8 \mathrm{H}, \mathrm{R}_{3} \mathrm{~N}-\left(\mathrm{CH}_{2}\right)_{2}-\right.$ $\mathrm{CH}_{2}-\mathrm{CH}_{3}$ ), 1.82 (q, br, $8 \mathrm{H}, \mathrm{R}_{3} \mathrm{~N}-\mathrm{CH}_{2}-\mathrm{CH}_{2}-\mathrm{CH}_{2}-\mathrm{CH}_{3}$ ), 3.46 (t, $\left.8 \mathrm{H},{ }^{3} \mathrm{~J}=8 \mathrm{~Hz}, \mathrm{R}_{3} \mathrm{~N}-\mathrm{CH}_{2}-\left(\mathrm{CH}_{2}\right)_{2}-\mathrm{CH}_{3}\right) \mathrm{ppm}$; ESR (acetone): $g=2.0039$; UV/Vis (acetone): $\lambda_{\max }\left(E_{\text {rel }}\right)=477$ (1.00), 611 (0.28), 686 (0.11), $761(0.18) \mathrm{nm} ; \mathrm{MS}\left(\mathrm{FAB}^{-}\right): \mathrm{m} / \mathrm{z}$ $(\%)=606.4(100)\left[\mathrm{M}^{-}\left(\mathrm{C}_{36} \mathrm{H}_{50} \mathrm{~N}_{2} \mathrm{O}_{6}^{-}\right)\right]$; HRMS: $\mathrm{m} / z$ calcd. $606.3674\left(\mathrm{C}_{36} \mathrm{H}_{50} \mathrm{~N}_{2} \mathrm{O}_{6}{ }^{-}\right)$, found 606.3658, $\Delta=-1.6 \mathrm{mmu}$.

2,7-Bis(2-hydroxymethyl-2-pentylheptyl)-3,6,8-trioxo-1,2,3,6,7,8-hexahydrobenzo[ $/ \mathrm{mn}][3,8]$ phenanthrolin-1-ol radical anion tetrabutylammonium salt $(5 \mathrm{~d}$, $\left.\mathrm{C}_{40} \mathrm{H}_{58} \mathrm{~N}_{2} \mathrm{O}_{6} \cdot \mathrm{C}_{16} \mathrm{H}_{36} \mathrm{~N}\right) 159 \mathrm{mg}$ 2,7-Bis(2-hydroxymethyl2-pentylheptyl)benzo[ $[\mathrm{mn}][3,8]$ phenanthroline-1,3,6,8tetraone (4d, $0.24 \mathrm{mmol})$ was allowed to react and purified as was described for 2,7-bis(2-ethyl-2-hydroxymethylbutyl)3,6,8-trioxo-1,2,3,6,7,8-hexahydrobenzo[ $\mathrm{lmn}][3,8]$ phenanthrolin-1-ol radical anion tetrabutylammonium salt (5a). Yield $207 \mathrm{mg}$ (95\%) brownish black solid; m.p.: $>300{ }^{\circ} \mathrm{C}$; IR (ATR): $\bar{v}=3332$ (m, br), 2956 (s), 2930 (m), 2871 (s), 1623 (s), $1586(\mathrm{~s}), 1556(\mathrm{~m}), 1519(\mathrm{~m}), 1487$ (w), $1464(\mathrm{~m}), 1424$ (w), $1400(\mathrm{w}), 1380(\mathrm{w}), 1365(\mathrm{w}), 1298(\mathrm{~m}), 1256(\mathrm{w})$, $1237(\mathrm{w}), 1189$ (w), $1171(\mathrm{w}), 1141(\mathrm{w}), 1089(\mathrm{w}), 1057$ (w), $1029(w), 1012(w), 979(w), 958(w), 932(w), 879(w), 833$ (w), 812 (w), 759 (w), 739 (w) cm ${ }^{-1}$; ${ }^{1} \mathrm{H}$ NMR $(400 \mathrm{MHz}$, acetone- $\left.d_{6}\right): \delta=0.98\left(\mathrm{t}, 12 \mathrm{H},{ }^{3} J=7 \mathrm{~Hz}, \mathrm{R}_{3} \mathrm{~N}-\left(\mathrm{CH}_{2}\right)_{3}-\right.$ $\left.\mathrm{CH}_{3}\right), 1.43\left(\mathrm{~m}, 8 \mathrm{H}, \mathrm{R}_{3} \mathrm{~N}-\left(\mathrm{CH}_{2}\right)_{2}-\mathrm{CH}_{2}-\mathrm{CH}_{3}\right), 1.83$ (q, br, $\left.8 \mathrm{H}, \mathrm{R}_{3} \mathrm{~N}-\mathrm{CH}_{2}-\mathrm{CH}_{2}-\mathrm{CH}_{2}-\mathrm{CH}_{3}\right), 3.45\left(\mathrm{t}, 8 \mathrm{H},{ }^{3} \mathrm{~J}=8 \mathrm{~Hz}\right.$, $\left.\mathrm{R}_{3} \mathrm{~N}-\mathrm{CH}_{2}-\left(\mathrm{CH}_{2}\right)_{2}-\mathrm{CH}_{3}\right)$ ppm; ESR (acetone): $g=2.0040$; $\mathrm{UV} / \mathrm{Vis}$ (acetone): $\lambda_{\max }\left(E_{\text {rel }}\right)=477(1.00), 611(0.55), 686$ (0.46), $761(0.51) \mathrm{nm} ; \mathrm{MS}\left(\mathrm{FAB}^{-}\right): m / z(\%)=662.4(100)$ $\left[\mathrm{M}^{-}\left(\mathrm{C}_{40} \mathrm{H}_{58} \mathrm{~N}_{2} \mathrm{O}_{6}^{-}\right)\right]$; HRMS $\left(\mathrm{C}_{40} \mathrm{H}_{58} \mathrm{~N}_{2} \mathrm{O}_{6}^{-}\right): \mathrm{m} / z$ calcd. 662.4300 , found $662.4233, \Delta=-6.7 \mathrm{mmu}$. 
$N, N^{\prime}$-Bis(1-hexylheptyl)-N"-(2-hydroxymethyl-2-octyldecyl)benzoperylene-1', 2', 3,4,9,10-hexacarboxylic acid $1^{\prime}, 2^{\prime}: 3,4: 9,10$-trisimide radical anion tetrabutylammonium salt (5e, $\left.\mathrm{C}_{52} \mathrm{H}_{81} \mathrm{~N}_{2} \mathrm{O}_{5} \cdot \mathrm{C}_{16} \mathrm{H}_{36} \mathrm{~N}\right) 47 \mathrm{mg} N, N^{\prime \prime}$-Bis(1hexylheptyl)- $N^{\prime}$-(2-hydroxy methyl-2-octyldecyl) benzoperylene-1', $2^{\prime}, 3,4,9,10$-hexacarboxylic acid $1^{\prime}, 2^{\prime}: 3,4: 9,10$-trisimide $(\mathbf{4 e}, 42 \mu \mathrm{mol})$ was allowed to react and purified as was described for 2,7-bis(2ethyl-2-hydroxymethylbutyl)-3,6,8-trioxo-1,2,3,6,7,8hexahydrobenzo[lmn $][3,8]$ phenanthrolin-1-ol radical anion tetrabutylammonium salt (5a). Yield $38 \mathrm{mg}$ green solid; UV/ Vis (acetone): $\lambda_{\max }\left(E_{\text {rel }}\right)=646(1.00), 721$ (0.59), $863(0.88)$ nm.

2,9-Bis(2-ethyl-2-hydroxymethylbutyl)anthra[2,1,9-def;$6,5,10 d^{\prime} e^{\prime} f^{\prime}$ ]diisoquinoline-1,3,8,10-tetraone radical anion tetrabutylammonium salt $\left(8 \mathrm{a}, \mathrm{C}_{38} \mathrm{H}_{38} \mathrm{~N}_{2} \mathrm{O}_{6} \cdot \mathrm{C}_{16} \mathrm{H}_{36} \mathrm{~N}\right) 148 \mathrm{mg}$ 2,9-Bis(2-ethyl-2-hydroxymethylbutyl)anthra[2, 1,9def;6,5,10- $\left.d^{\prime} e^{\prime} f^{\prime}\right]$ diisoquinoline-1,3,8,10-tetraone (7a, $239 \mu \mathrm{mol})$ under argon was dispersed in degassed $0.5 \mathrm{~cm}^{3}$ ethanol, treated with $1 \mathrm{~cm}^{3}$ degassed distilled water and $1 \mathrm{~cm}^{3} 30 \%$ aqueous $\mathrm{NaOH}$, heated at $50-55{ }^{\circ} \mathrm{C}$, treated with $1 \mathrm{~cm}^{3}$ hydroxyacetone $(15 \mathrm{mmol})$, stirred for $10 \mathrm{~min}$, treated with $1.0 \mathrm{~g}$ tetrabutylammonium bromide $(3.1 \mathrm{mmol})$ in $1.5 \mathrm{~g}$ degassed distilled water, diluted with $10 \mathrm{~cm}^{3}$ degassed distilled water, stirred at $0{ }^{\circ} \mathrm{C}$ for $10 \mathrm{~min}$, collected by vacuum filtration under argon, washed with degassed distilled water until colorless washings, dried in medium vacuum and then in a counter current of nitrogen over phosphorous pentoxide. Yield $242 \mathrm{mg}$ violet powder; m.p.: $>300^{\circ} \mathrm{C}$; IR (ATR): $\bar{v}=3228$ (br, m), 1600 (s), 1560 (m), 1541 (s), $1491(\mathrm{~m}), 1468$ (m), 1437 (m), 1415 (m), 1378 (m), 1358 (m), 1327 (s), 1297 (w), 1228 (m), 1208 (w), 1177 (w), $1145(\mathrm{~m}), 1087$ (w), 1051 (w), 999 (w), $968(\mathrm{w}), 928(\mathrm{w}), 875(\mathrm{w}), 820(\mathrm{w}), 788(\mathrm{~s}), 752(\mathrm{w}), 735$ (w), $700(\mathrm{w}), 632(\mathrm{w}), 579(\mathrm{w}) \mathrm{cm}^{-1}$; ${ }^{1} \mathrm{H}$ NMR $(400 \mathrm{MHz}$, acetone- $\left.d_{6}\right): \delta=0.97\left(\mathrm{t}, 12 \mathrm{H},{ }^{3} \mathrm{~J}=7.3 \mathrm{~Hz}, \mathrm{~N}-\left(\mathrm{CH}_{2}\right)_{3}-\mathrm{CH}_{3}\right)$, $1.37-1.46\left(\mathrm{~m}, 8 \mathrm{H},{ }^{3} \mathrm{~J}=7.3 \mathrm{~Hz}, 7.2 \mathrm{~Hz}, \mathrm{~N}-\left(\mathrm{CH}_{2}\right)_{2}-\mathrm{CH}_{2}-\right.$ $\left.\mathrm{CH}_{3}\right), 1.80$ (m, br, 8H, N-CH $\left.-\mathrm{CH}_{2}-\mathrm{CH}_{2}-\mathrm{CH}_{3}\right), 3.41-3.45$ (t, $8 \mathrm{H},{ }^{3} \mathrm{~J}=7.7 \mathrm{~Hz} \mathrm{~N}-\mathrm{CH}_{2}-\mathrm{CH}_{2}-\mathrm{CH}_{2}-\mathrm{CH}_{3}$ ) ppm; ESR (acetone): $g=2.0038$; UV/Vis (acetone): $\lambda_{\max }(\varepsilon)=680$ (40,000), 702 (60,000), 711 (60,000), 767 (20,000), 797 (40,000), $957(20,000) \mathrm{nm}\left(\mathrm{dm}^{3} \mathrm{~mol}^{-1} \mathrm{~cm}^{-1}\right) ; \mathrm{MS}\left(\mathrm{FAB}^{-}\right)$: $m / \mathrm{z}(\%)=618.3(100)\left[\mathrm{C}_{38} \mathrm{H}_{38} \mathrm{~N}_{2} \mathrm{O}_{6}{ }^{-}\right]$; HRMS: $\mathrm{m} / z$ calcd. $618.2735\left(\mathrm{C}_{38} \mathrm{H}_{38} \mathrm{~N}_{2} \mathrm{O}_{6}^{-}\right)$, found 618.2730, $\Delta=-0.5 \mathrm{mmu}$.

\section{2,9-Bis(2-hydroxymethyl-2-propylpentyl)anthra[2,1,9-def;-} $6,5,10-d^{\prime} e^{\prime} f^{\prime}$ ] diisoquinoline-1,3,8,10-tetraone radical anion tetrabutylammonium salt $\left(8 \mathrm{~b}, \mathrm{C}_{42} \mathrm{H}_{46} \mathrm{~N}_{2} \mathrm{O}_{6}\right.$. $\left.\mathrm{C}_{16} \mathrm{H}_{36} \mathrm{~N}\right) 164 \mathrm{mg}$ 2,9-Bis(2-hydroxymethyl-2-propylpentyl)anthra[2,1,9-def;6,5,10-d'e'f']diisoquinoline-1,3,8,10tetraone $(\mathbf{7 b}, 243 \mu \mathrm{mol})$ was allowed to react and purified as was described for 2,9-bis(2-ethyl-2-hydroxymethylbutyl) anthra[2,1,9-def;6,5,10-d'e'f']diisoquinoline-1,3,8,10tetraone radical anion tetrabutylammonium salt $(\mathbf{8 a})$. Yield $254 \mathrm{mg}$ violet solid; m.p.: $>300{ }^{\circ} \mathrm{C}$; IR (ATR): $\bar{v}=3525$ (w), 3257 (br, m), 2957 (s), 2932 (s), 2872 (m), 1601 (s), $1542(\mathrm{~s}), 1492(\mathrm{~m}), 1466(\mathrm{~m}), 1436(\mathrm{w}), 1414(\mathrm{w}), 1379(\mathrm{w})$, 1359 (m), 1328 (s), 1294 (m), 1226 (m), 1208 (vw), 1177 (vw), 1145 (m), 1103 (w), 1081 (vw), 1057 (m), 1016 (vw), $955(\mathrm{vw}), 928(\mathrm{w}), 879(\mathrm{w}), 850(\mathrm{vw}), 788(\mathrm{~m}), 744(\mathrm{~m})$, $701(\mathrm{~m}) \mathrm{cm}^{-1} ;{ }^{1} \mathrm{H}$ NMR (400 MHz, acetone- $d_{6}$ ): $\delta=0.97$ (t, $\left.12 \mathrm{H}, \mathrm{N}-\left(\mathrm{CH}_{2}\right)_{3}-\mathrm{CH}_{3}\right), 1.39-1.43\left(\mathrm{~m}, \mathrm{br}, 8 \mathrm{H}, \mathrm{N}-\left(\mathrm{CH}_{2}\right)_{2}-\right.$ $\left.\mathrm{CH}_{2}-\mathrm{CH}_{3}\right), 1.77-1.82\left(\mathrm{~m}, \mathrm{br}, 8 \mathrm{H}, \mathrm{N}-\mathrm{CH}_{2}-\mathrm{CH}_{2}-\mathrm{CH}_{2}-\mathrm{CH}_{3}\right.$ ), 3.41-3.45 (m, br, $\left.8 \mathrm{H}, \mathrm{N}-\mathrm{CH}_{2}-\mathrm{CH}_{2}-\mathrm{CH}_{2}-\mathrm{CH}_{3}\right)$ ppm; ESR (solid state): $g=2.0041$; ESR (acetone): $g=2.0038$; UV/ Vis (acetone): $\lambda_{\max }(\varepsilon)=680(40,000), 702(60,000), 711$ (60,000), 767 (20,000), 797 (40,000), $957(20,000) \mathrm{nm}$ $\left(\mathrm{dm}^{3} \mathrm{~mol}^{-1} \mathrm{~cm}^{-1}\right)$; MS (-p ESI): $\mathrm{m} / z(\%)=674(100)$ $\left[\mathrm{M}^{-}\left(\mathrm{C}_{42} \mathrm{H}_{46} \mathrm{~N}_{2} \mathrm{O}_{6}{ }^{-}\right)\right]$; MS (+p ESI): $m / z(\%)=243(100)$ $\left[\mathrm{C}_{16} \mathrm{H}_{36} \mathrm{~N}^{+}\right.$]; HRMS: $m / z$ calcd. $674.3361\left(\mathrm{C}_{42} \mathrm{H}_{46} \mathrm{~N}_{2} \mathrm{O}_{6}{ }^{-}\right)$, found 674.3359, $\Delta=-0.2 \mathrm{mmu}$; calcd. 242.2842 $\left(\mathrm{C}_{16} \mathrm{H}_{36} \mathrm{~N}^{+}\right)$, found 242.2839, $\Delta=-0.3 \mathrm{mmu}$.

2,9-Bis(2-hydroxymethyl-2-propylpentyl)anthra[2,1,9-def;6,5,10- $d^{\prime} e^{\prime} f^{\prime}$ ]diisoquinoline-1,3,8,10-tetraone radical anion tetrabutylammonium salt $\left(8 \mathrm{~b}, \mathrm{C}_{42} \mathrm{H}_{46} \mathrm{~N}_{2} \mathrm{O}_{6} \cdot \mathrm{C}_{16} \mathrm{H}_{36} \mathrm{~N}\right)$; precipitation of the radical anion with tetrabutylammonium hydrogen sulfate $164 \mathrm{mg}$ 2,9-bis(2-hydroxymethyl-2propylpentyl)-anthra[2,1,9-def;6,5,10-d'e'f']diisoquinoline1,3,8,10-tetraone $(\mathbf{7 b}, 243 \mu \mathrm{mol})$ and $1.1 \mathrm{~g}$ tetrabutylammonium hydrogensulfate $(3.1 \mathrm{mmol})$ in $1.5 \mathrm{~cm}^{3}$ degassed distilled water were allowed to react and purified as was described for 2,9-bis(2-ethyl-2-hydroxymethylbutyl) anthra[2,1,9-def;6,5,10d'e'f']diisoquinoline-1,3,8,10-tetraone radical anion tetrabutylammonium salt (7a). Yield $254 \mathrm{mg}$ violet solid; IR (ATR): $\bar{v}=3525$ (w), 3257 (br, m), 2957 (s), $2932(\mathrm{~s}), 2872(\mathrm{~m}), 1601(\mathrm{~s}), 1542(\mathrm{~s}), 1492(\mathrm{~m}), 1466(\mathrm{~m})$, 1436 (w), 1414 (w), 1379 (w), 1359 (m), 1328 (s), 1294 (m), 1226 (m), 1208 (vw), 1177 (vw), 1145 (m), 1103 (w), 1081 (vw), $1057(\mathrm{~m}), 1016(\mathrm{vw}), 955(\mathrm{vw}), 928(\mathrm{w}), 879(\mathrm{w}), 850$ (vw), $788(\mathrm{~m}), 744(\mathrm{~m}), 701(\mathrm{~m}) \mathrm{cm}^{-1}$; UV/Vis (acetone): $\lambda_{\max }(\varepsilon)=680(40,000), 702(60,000), 711(60,000), 767$ (20,000), 797 (40,000), $957(20,000) \mathrm{nm}\left(\mathrm{dm}^{3} \mathrm{~mol}^{-1} \mathrm{~cm}^{-1}\right)$.

2,9-Bis(2-hydroxymethyl-2-butyloctyl)anthra[2,1,9-def;6,5,10-d $e^{\prime} f^{\prime}$ ]diisoquinoline-1,3,8,10-tetraone radical anion tetrabutylammonium salt $\left(8 \mathrm{C}, \mathrm{C}_{46} \mathrm{H}_{54} \mathrm{~N}_{2} \mathrm{O}_{6}\right.$. $\mathrm{C}_{16} \mathrm{H}_{36} \mathrm{~N}$ ) $177 \mathrm{mg}$ 2,9-Bis(2-hydroxymethyl-2-butyloctyl) anthra[2,1,9-def;6,5,10- $\left.d^{\prime} e^{\prime} f^{\prime}\right]$ diisoquinoline 1,3,8,10tetraone (7c, $242 \mu \mathrm{mol})$ was allowed to react and purified as was described for 2,9-bis(2-ethyl-2-hydroxymethylbutyl)anthra[2,1,9-def;6,5,10-d'e'f']diisoquinoline-1,3,8,10tetraone radical anion tetrabutylammonium salt (8a). Yield $277 \mathrm{mg}$ violet solid; m.p.: $>300^{\circ} \mathrm{C}$; IR (ATR): $\bar{v}=3236$ (br, m), 2957 (s), 2930 (s), 2871 (m), 1600 (s), 1541 (s), 1492 
(m), 1466 (m), $1436(\mathrm{w}), 1413(\mathrm{w}), 1378(\mathrm{w}), 1359(\mathrm{~m})$, 1328 (s), 1296 (m), 1229 (m), 1208 (w), 1177 (vw), 1145 (m), 1104 (w), 1086 (vw), $1053(\mathrm{~m}), 935$ (w), 876 (w), 795 (m), 788 (m), 742 (m) 702 (m) 647 (w) $\mathrm{cm}^{-1} ;{ }^{1} \mathrm{H}$ NMR (400 MHz, acetone- $\left.d_{6}\right): \delta=0.97\left(\mathrm{t}, 12 \mathrm{H},-\mathrm{CH}_{3}\left(\mathrm{C}_{16} \mathrm{H}_{36} \mathrm{~N}^{+}\right)\right.$), 1.41-1.43 (m, br, 8H, $-\mathrm{CH}_{2}-\mathrm{CH}_{3}\left(\mathrm{C}_{16} \mathrm{H}_{36} \mathrm{~N}^{+}\right)$), 1.80-1.82 (m, br, $8 \mathrm{H},-\mathrm{CH}_{2}-\mathrm{CH}_{2}-\mathrm{CH}_{3}\left(\mathrm{C}_{16} \mathrm{H}_{36} \mathrm{~N}^{+}\right)$), 3.45-3.46 (t, br, $\left.8 \mathrm{H},-\mathrm{CH}_{2}-\mathrm{N}\left(\mathrm{C}_{16} \mathrm{H}_{36} \mathrm{~N}^{+}\right)\right)$ppm; ESR (acetone): $g=2.0037$; UV/Vis (acetone): $\lambda_{\text {max }}\left(E_{\text {rel }}\right)=680(0.62), 701(0.98), 710$ (1.00), 766 (0.26), 796 (0.57), 957 (0.36) nm; MS (FAB $\left.{ }^{-}\right)$: $m / z \quad \%)=730.4(100)\left[\mathrm{M}^{-}\left(\mathrm{C}_{46} \mathrm{H}_{54} \mathrm{~N}_{2} \mathrm{O}_{6}{ }^{-}\right)\right]$; HRMS: $m / z$ calcd. $730.3987\left(\mathrm{C}_{46} \mathrm{H}_{54} \mathrm{~N}_{2} \mathrm{O}_{6}{ }^{-}\right)$, found 730.3982 , $\Delta=-0.5 \mathrm{mmu}$.

2,9-Bis(2-hydroxymethyl-2-pentylheptyl)anthra[2,1,9-def;$6,5,10-d^{\prime} e^{\prime} f^{\prime}$ ]diisoquinoline-1,3,8,10-tetraone radical anion tetrabutylammonium salt $\left(\mathbf{8 d}, \mathrm{C}_{50} \mathrm{H}_{62} \mathrm{~N}_{2} \mathrm{O}_{6}\right.$. $\left.\mathrm{C}_{16} \mathrm{H}_{36} \mathrm{~N}\right) 189 \mathrm{mg}$ 2,9-Bis(2-hydroxymethyl-2-pentylheptyl)anthra[2,1,9-def;6,5,10-d'e'f']diisoquinoline-1,3,8,10tetraone (7d, $240 \mathrm{mmol}$ ) was allowed to react and purified as was described for 2,9-bis(2-ethyl-2-hydroxymethylbutyl)anthra[2,1,9-def;6,5,10-d'e'f']diisoquinoline-1,3,8,10tetraone radical anion tetrabutylammonium salt $(\mathbf{8 a})$. Yield $346 \mathrm{mg}$ violet solid; m.p.: $>300{ }^{\circ} \mathrm{C}$; IR (ATR): $\bar{v}=3250$ (br, m), 2955 (s), 2928 (s), 2871 (m), 1600 (s), 1561 (w), 1543 (s), 1488 (m), 1466 (m), 1377 (w), 1360 (m), 1330 (s), $1296(\mathrm{~m}), 1229(\mathrm{~m}), 1204(\mathrm{vw}), 1145(\mathrm{~m}), 1105(\mathrm{w})$, 1067 (m), 949 (vw), $878(\mathrm{w}), 788$ (m), 741 (m), 702 (m), $646(\mathrm{w}) \mathrm{cm}^{-1} ;{ }^{1} \mathrm{H}$ NMR $\left(400 \mathrm{MHz}\right.$, acetone- $\left.d_{6}\right): \delta=0.98(\mathrm{t}$, $\left.12 \mathrm{H},-\mathrm{CH}_{3}\left(\mathrm{C}_{16} \mathrm{H}_{36} \mathrm{~N}^{+}\right)\right), 1.40-1.46\left(\mathrm{~m}, \mathrm{br}, 8 \mathrm{H}, \mathrm{CH}_{2}-\mathrm{CH}_{3}\right.$ $\left.\left(\mathrm{C}_{16} \mathrm{H}_{36} \mathrm{~N}^{+}\right)\right), 1.82\left(\mathrm{~m}, \mathrm{br}, 8 \mathrm{H},-\mathrm{CH}_{2}-\mathrm{CH}_{2}-\mathrm{CH}_{3}\left(\mathrm{C}_{16} \mathrm{H}_{36} \mathrm{~N}^{+}\right)\right)$, 3.47-3.48 (t, br, $\left.8 \mathrm{H},-\mathrm{CH}_{2}-\mathrm{N}\left(\mathrm{C}_{16} \mathrm{H}_{36} \mathrm{~N}^{+}\right)\right)$ppm; ESR (acetone): $g=2.0037$; UV/Vis (acetone): $\lambda_{\text {max }}\left(E_{r e l}\right)=956(0.36)$, 796 (0.58), 766 (0.28), 711 (1.00), 701 (0.98), 680 (0.63) $\mathrm{nm} ; \mathrm{MS}(-p \mathrm{ESI}): m / z(\%)=786(50)\left[\mathrm{M}^{-}\left(\mathrm{C}_{50} \mathrm{H}_{62} \mathrm{~N}_{2} \mathrm{O}_{6}{ }^{-}\right)\right]$; MS $\left(+p\right.$ ESI): $m / z(\%)=242(100)\left[\mathrm{C}_{16} \mathrm{H}_{36} \mathrm{~N}^{+}\right]$; HRMS: $m / z$ calcd. $786.4631\left(\mathrm{C}_{50} \mathrm{H}_{62} \mathrm{~N}_{2} \mathrm{O}_{6}{ }^{-}\right)$, found 786.4607, $\Delta=-2.4 \mathrm{mmu}$; calcd. $242.2842\left(\mathrm{C}_{16} \mathrm{H}_{36} \mathrm{~N}^{+}\right)$, found 242.2838, $\Delta=-0.4 \mathrm{mmu}$.

2,9-Bis(2-hydroxymethyl-2-octyldecyl)anthra[2,1,9-def;$6,5,10-d^{\prime} e^{\prime} f^{\prime}$ ]diisoquinoline-1,3,8,10-tetraone radical anion tetrabutylammonium salt (8e, $\left.\mathbf{C}_{62} \mathrm{H}_{86} \mathbf{N}_{2} \mathbf{O}_{6} \cdot \mathbf{C}_{16} \mathrm{H}_{36} \mathrm{~N}\right) 229 \mathrm{mg}$ 2,9-Bis(2-hydroxymethyl-2-octyldecyl)anthra[2,1,9def;6,5,10-d'e'f']diisoquinoline-1,3,8,10-tetraone (7e, $240 \mu \mathrm{mol})$ was allowed to react an purified as was described for 2,9-bis(2-ethyl-2-hydroxymethylbutyl)anthra[2,1,9def;6,5,10d'e'f']diisoquinoline-1,3,8,10-tetraone radical anion tetrabutylammonium salt (8a). Yield $294 \mathrm{mg}$ violet solid; m.p.: $230{ }^{\circ} \mathrm{C}$; IR (ATR): $\bar{v}=3449$ (br, w), 3239 (br, w), 2957 (m), 2922 (s), 2852 (m), 1601 (s), 1541 (s), 1490 (m), 1464 (m), 1439 (m), 1361 (w), 1329 (s), 1297 (m), 1228 (m), 1208 (w), 1176 (w), 1147 (m), 1096 (w), 1054 (w), 1024 (w), $940(\mathrm{w}), 912(\mathrm{w}), 876(\mathrm{w}), 788(\mathrm{~s}), 740(\mathrm{~s}), 724(\mathrm{w})$, $703(\mathrm{~m}), 648(\mathrm{w}) \mathrm{cm}^{-1}$; ESR (acetone): $g=2.0038$; UV/Vis (acetone): $\lambda_{\text {max }}\left(E_{r e l}\right)=957$ (0.48), 797 (0.63), 767 (0.29), 711 (1.00), 701 (0.97), 680 (0.61) nm; MS (FAB $\left.{ }^{-}\right): m / z$ $(\%)=954.7$ (100) $\left[\mathrm{M}^{-}\left(\mathrm{C}_{62} \mathrm{H}_{86} \mathrm{~N}_{2} \mathrm{O}_{6}{ }^{-}\right)\right]$; HRMS: $m / z$ calcd . 954.6491 $\left(\mathrm{C}_{62} \mathrm{H}_{86} \mathrm{~N}_{2} \mathrm{O}_{6}{ }^{-}\right)$, found 954.6486, $\Delta=-0.5 \mathrm{mmu}$.

2,9-Bis(1-hexylheptyl)anthra[2,1,9-def;6,5,10-d' $\left.e^{\prime} f^{\prime}\right]$ diisoquinoline-1,3,8,10-tetraone radical anion tetrabutylammonium salt $\left(\mathbf{2}, \boldsymbol{n}=\mathbf{2}, \mathbf{C}_{50} \mathbf{H}_{62} \mathbf{N}_{2} \mathbf{O}_{4} \cdot \mathbf{C}_{16} \mathbf{H}_{36} \mathbf{N}\right) 180 \mathrm{mg} \mathrm{N}, N^{\prime}-$ B is (1-hexylheptyl)anthra[2,1,9-def; 6,5,10-d'e'f'] diisoquinoline-1,3,8,10-tetraone $(\mathbf{1}, n=2 ; 0.24 \mathrm{mmol})$ was allowed to react and purified as was described for 2,9-bis(2ethyl-2-hydroxymethylbutyl)anthra[2,1,9-def;6,5,10d' $\left.e^{\prime} f^{\prime}\right]$ diisoquinoline-1,3,8,10-tetraone radical anion tetrabutylammonium salt (8a). Yield $197 \mathrm{mg}(197 \mu \mathrm{mol}, 82 \%)$ violet solid; IR (ATR): $\bar{v}=2958$ (s), 2924 (vs), 2856 (s), 1582 (vs), 1561 (s), 1524 (s), 1489 (s), 1362 (m), 1318 (s), 1228 (w), 1132 (w), 1100 (w), 782 (w), $742 \mathrm{~cm}^{-1}$ (w) $\mathrm{cm}^{-1}$; UV/Vis (acetone): $\lambda_{\text {max }}\left(E_{\text {rel }}\right)=680(0.61), 700$ (1.00), $711(0.92)$, 766 (0.37), 796 (0.60), 957 (0.43) nm; ESR (acetone): $g=2.0037$; ESR (solid state): $g=2.0041 ; \mathrm{MS}\left(\mathrm{FAB}^{-}\right): m / z$ $(\%)=754$ (20) $\left[\mathrm{M}^{-}\left(\mathrm{C}_{50} \mathrm{H}_{62} \mathrm{~N}_{2} \mathrm{O}_{4}{ }^{-}\right)\right]$; HRMS: $m / z$ calcd . $754.4715\left(\mathrm{C}_{50} \mathrm{H}_{62} \mathrm{~N}_{2} \mathrm{O}_{4}{ }^{-}\right)$, found 754.4756, $\Delta=0.5 \mathrm{mmu}$.

$N, N^{\prime}$-Bis(1-hexylheptyl)quaterrylene-3,4,13,14-tetracarboxylic acid 3,4:13,14-diimide radical anion tetrabutylammonium salt (14, $\left.\mathrm{C}_{70} \mathrm{H}_{70} \mathrm{~N}_{2} \mathbf{O}_{4} \cdot \mathrm{C}_{16} \mathrm{H}_{36} \mathrm{~N}\right) 50 \mathrm{mg} N, N^{\prime}$-Bis(1-hexylheptyl)quaterrylene-3,4,13,14-tetracarboxylic acid 3,4:13,14-diimide $(13,50 \mu \mathrm{mol})$ was allowed to react and purified as was described for 2,7-bis(2-ethyl-2-hydroxymethylbutyl)-3,6,8trioxo-1,2,3,6,7,8-hexahydrobenzo[lmn][3,8]phenanthrolin1-ol radical anion tetrabutylammonium salt (8a). Yield $63 \mathrm{mg}$ (99\%) green solid; IR (ATR): $\bar{v}=2957(\mathrm{~m}), 2924(\mathrm{~m}), 2855$ (m), 1643 (m), 1564 (s), 1532 (m), 1504 (m), 1480 (w), 1465 (m), 1376 (m), 1364 (m), 1332 (s), 1292 (w), 1277 (w), 1242 (s), 1203 (w), $1180(\mathrm{w}), 1144(\mathrm{w}), 1104(\mathrm{w}), 1048(\mathrm{w}), 937$ (w), 883 (w), $806(\mathrm{w}), 780(\mathrm{~m}), 748(\mathrm{~m}), 664(\mathrm{w}), 608(\mathrm{w})$, $588(\mathrm{w}) \mathrm{cm}^{-1}$; UV/Vis (acetone): $\lambda_{\max }\left(E_{r e l}\right)=1075(1.00)$, 1185 (0.16), 1251 (0.30), 1697 (0.20) nm; MS (FAB $\left.{ }^{-}\right): m / z$ $(\%)=1002.5$ (100) $\left[\mathrm{M}^{-}\left(\mathrm{C}_{70} \mathrm{H}_{70} \mathrm{~N}_{2} \mathrm{O}_{4}^{-}\right)\right]$; HRMS: $\mathrm{m} / z$ calcd . $1002.5341\left(\mathrm{C}_{70} \mathrm{H}_{70} \mathrm{~N}_{2} \mathrm{O}_{4}{ }^{-}\right)$, found 1002.5372, $\Delta=3.1 \mathrm{mmu}$.

\section{Exemplary procedure for reduction and immediate UV/Vis spectroscopic measurement}

2,9-Bis(1-hexylheptyl)anthra[2,1,9-def;6,5,10-d'e'f']diisoquinoline-1,3,8,10-tetraone $(\mathbf{1}, n=2 ; 1.0 \mathrm{mg}, 1.3 \mu \mathrm{mol})$ was reduced according to $\mathbf{5 a}$ or $\mathbf{8 a}$, respectively; however, instead of precipitation, a definite small amount of the solution was added under argon to a stock solution consisting of $0.8 \mathrm{~cm}^{3}$ DBU ( $8 \mathrm{mmol}), 0.5 \mathrm{~cm}^{3}$ hydroxyl acetone $(7 \mathrm{mmol})$, and $1 \mathrm{~cm}^{3}$ diacetyl $(11 \mathrm{mmol})$ dissolved in a small amount of 
spectroscopically pure acetone being quickly completed to $25 \mathrm{~cm}^{3}$ by means of acetone and measured against the stock solution (if the time until completing is too long decomposition to brown products will proceed perturbing the measurements).

Acknowledgements Open access funding provided by Austrian Science Fund (FWF). We acknowledge financial support of the Austrian Science Foundation (FWF) [Z 222-N19] within the Wittgenstein Prize for Prof. Sariciftci.

Open Access This article is distributed under the terms of the Creative Commons Attribution 4.0 International License (http://creativeco mmons.org/licenses/by/4.0/), which permits unrestricted use, distribution, and reproduction in any medium, provided you give appropriate credit to the original author(s) and the source, provide a link to the Creative Commons license, and indicate if changes were made.

\section{References}

1. Roncali J (1997) Chem Rev 97:173

2. Zollinger H (2003) Color chemistry: syntheses, properties, and applications of organic dyes and pigments. Wiley, Weinheim

3. Daehne S, Resch-Genger U, Wolfbeis OE (1998) Near-infrared dyes for high technology applications. Springer, Dordrecht

4. Nolting DD, Gore JC, Pham W (2011) Curr Org Synth 8:521

5. Langhals H (2014) J Electr Electron Syst 3:125

6. Langhals H, Ritter, U (2008) Eur J Org Chem 3912

7. Langhals H, Jaschke H (2006) Chem Eur J 12:2815

8. Langhals H, Zgela D, Lüling R (2015) J Org Chem 80:12146

9. Nelsen SF (1967) J Am Chem Soc 89:5925

10. Hassel T, Hocker J, Müller HK, Fitzky HG (1987) Radical anion salts of 1,4,5,8-naphthalenetetracarboxylic acid derivatives, process for their preparation, and their use. Eur Pat Appl EP 224779, Jun 10, 1987 (Chem Abstr 107:210492)

11. Andric G, Boas JF, Bond AM, Fallon GD, Ghiggino KP, Hogan CF, Hutchison JA, Lee MAP, Langford SJ, Pilbrow JR, Trodsgup GJ, Woodward CP (2004) Aust J Chem 57:1011

12. Heywang G (1991) Method of preparing naphthalenetetracarboxylic acid dianhydride and -(poly)bisimide radical anion salts. Ger Offen DE 3937592, May 16, 1991 (Chem Abstr 115:256152)

13. Reszka KJ, Takayama M, Sik RH, Chignell CF, Saito I (2005) Photochem Photobiol 81:573

14. Bélanger-Chabot G, Ali A, Gabbai FP (2017) Angew Chem 129:10090 (Angew Chem Int Ed 56:9958)

15. Wu Y, Krzyaniak MD, Stoddart JF, Wasielewski MR (2017) J Am Chem Soc 139:2948

16. Nalluri SKM, Liu Z, Wu Y, Hermann KR, Samanta A, Kim DJ, Krzyaniak MD, Wasielewski MR, Stoddart JF (2016) J Am Chem Soc 138:5968

17. Mizuno A, Shuku Y, Suizu R, Matsushita MM, Tsuchiizu M, Reta MD, Illas F, Robert V, Awaga K (2015) J Am Chem Soc 137:7612

18. Gosztola D, Niemczyk MP, Svec W, Lukas AS, Wasielewski MR (2000) J Phys Chem A 104:6545

19. Langhals H, Jaschke H, Bastani-Oskoui H, Speckbacher M (2005) Eur J Org Chem:4313

20. Langhals H, v. Unold P (1995) Angew Chem 107:2436 (Angew Chem Int Ed 34:2234)

21. Truscheit E, Eiter K (1962) Justus Liebigs Ann Chem 658:65

22. Möller F (1965) Preparation of bicyclic amidines. Fr Demande FR 1491791, Sept 9, 1965 (Chem Abstr 69:67412)
23. Oediger H, Möller F (1967) Angew Chem 79:53 (Angew Chem Int Ed 6:76)

24. Langhals H, Bastani-Oskoui H (1997) J Prakt Chem 339:597

25. De Blase CR, Hernandez-Burgos K, Rotter JM, Fortman DJ, Abreu DS, Timm RA, Diogenes ICN, Kubota LT, Abruna HD, Dichtel WR (2015) Angew Chem Int Ed 54:13225

26. Ryabinin VA, Starichenko VF, Vorozhtsov GN, Shein SM (1978) Zh Struktur Khim 19:953

27. Vorozhtsov GN, Ryabinin VA, Starichenko VF, Shein SM (1982) Zh Org Khim 18:1024

28. Stasko A, Bartl A, Domschke G (1988) Zeitschr Chem 28:218

29. Salbeck J, Kunkely H, Langhals H, Saalfrank RW, Daub J (1989) Chimia 43:6

30. Roznyatovskiy VV, Gardner DM, Eaton SW, Wasielewski MR (2014) Org Lett 16:696

31. Langhals H (2005) Helv Chim Acta 88:1309

32. Langhals $H$ (1995) Heterocycles 40:477

33. Langhals H (2008) Molecular devices chiral, bichromophoric silicones: ordering principles in complex molecules. In: Ganachaud F, Boileau S, Boury B (eds) Silicon based polymers. Springer, Berlin, p 51

34. Langhals H (2013) Chromophores for picoscale optical computers. In: Sattler K (ed) Fundamentals of picoscience. Taylor \& Francis Inc. CRC Press Inc., Bosa Roca, p 705

35. Nolde F, Qu J, Kohl C, Pschirer NG, Reuther E, Müllen K (2005) Chem Eur J 11:3959

36. Lee SK, Zu Y, Herrmann A, Geerts Y, Müllen K, Bard AJ (1999) J Am Chem Soc 121:3513

37. Langhals H, Poxleitner S (2008) Eur J Org Chem:797

38. Langhals H, Poxleitner S (2007) Benzoterrylene derivatives with good fluorescence quantum yields. US Patent 20090056793, Aug 31, 2007 (Chem Abstr 150:308304)

39. Quante H, Müllen K (1995) Angew Chem Int Ed 43:1323

40. Nolde F, Pisula W, Müller S, Kohl C, Müllen K (2006) Chem Mater 18:3715

41. Langhals H, Büttner J, Blanke P (2005) Synthesis:364

42. Langhals H, Schönmann G, Feiler L (1995) Tetrahedron Lett 36:6423

43. Langhals H, Kirner S (2000) Eur J Org Chem:365

44. Langhals $H$ (1985) Chem Ber 118:4641

45. Langhals H, Grundei T, Potrawa T, Polborn K (1996) Liebigs Ann:679

46. Langhals H, Demmig S, Potrawa T (1991) J Prakt Chem 333:733

47. Piccard J (1926) J Am Chem Soc 48:2352 (Chem Abstr 20:25316)

48. Piccard J (1922) Rec Trav Chim 41:581 (Chem Abstr 17: 3515)

49. Piccard J (1918) Helv Chim Acta 1:134 (Chem Abstr 12:15048)

50. Piccard J (1913) Ber Dtsch Chem Ges 46:1843 (Chem Abstr 7:20362)

51. Veciana J, Iwamura H (2000) MRS Bull 25:41

52. Miller JS (2002) Adv Mater 14:1105

53. Crayston JA, Devine JN, Walton JC (2000) Tetrahedron 56:7829

54. Shelton WA, Aprà E, Sumpter BG, Saraiva-Souza A, Souza Filho AG, Del Nero J, Meunier V (2011) Chem Phys Lett 511:294

55. Rys P (2000) Colorchem 2000:L11

56. Langhals H, Jaschke H, Ehlis T, Wallquist O (2006) Naphthalene amidine imides useful as UV absorbers for cosmetics, etc. PCT Int Appl WO 2007012611, July 21, 2006 (Chem Abstr 146:185965)

57. Langhals H, Fuchs K (2004) Chem Unserer Zeit 38:98, 2004 (Chem Abstr 141:42490)

Publisher's Note Springer Nature remains neutral with regard to jurisdictional claims in published maps and institutional affiliations. 